\title{
SPELEOGENESIS OF CAVES IN A CRETACEOUS SHALE: BIGHORN BASIN, WYOMING
}

\author{
Douglas M. Medville ${ }^{1}$
}

\begin{abstract}
Blind valleys, aligned dolines, and openings leading to 50 to $70 \mathrm{~m}$ long, linear caves, developed entirely within the lower Cretaceous Cody Shale, are found along the west flank of a $150 \mathrm{~m}$ high and $7 \mathrm{~km}$ long ridge on the eastern side of the Bighorn Basin in north-central Wyoming. Precipitation events on a swelling soil allow water and oxygen to reach the shale a few meters below the surface and to react with pyrite in the shale. Microbially-assisted oxidation of the pyrite, possibly by Acidithiobacillus ferrooxidans, produces sulfuric acid that reacts with calcite in the shale, resulting in gypsum fracture fillings, observed as 2 to $4 \mathrm{~cm}$ thick beds on cave walls and sub-mm-diameter deposits within shale beds. Evidence for pyrite oxidation is provided by the presence of a ferric oxyhydroxide (goethite) as a by-product, visible as brown fillings on cave walls, confirmed by XRD. Stable sulfur isotope analysis, using gypsum samples taken from fracture fillings in the caves, was conducted with negative values for $\delta^{34} S$ obtained (versus positive values for marine sulfate), providing additional evidence for pyrite as the source of sulfur in the gypsum. This was confirmed by SEM imaging of shale samples. These samples showed gypsum inclusions in the shale, biofilm-coated, framboidal pyrite pseudomorphs, and iron oxyhydroxide residue remaining on the framboidal surfaces, evidence for pyrite oxidation. The $2 \times$ molar-volume increase, resulting from calcite re-crystallization to gypsum and subsequent growth of gypsum crystals, leads to fracturing and separation of individual shale beds, reducing the structural integrity of the shale. Disassociated shale beds along passage walls and rubble slopes of decomposed shale beneath the walls are evidence of shale decomposition. Subsequent dissolution of gypsum by meteoric water moving through beds and fractures in the shale results in the creation of small, localized voids. When wetted, the shale decomposes into micron-scale particles that are removed by episodic water flowing downslope. Sapping occurs at the places where sediment-laden water emerges, creating openings that progress headward. As material is removed on a grain-by-grain basis by corrasion, the small voids coalesce into more integrated spaces, ultimately permitting human entry.
\end{abstract}

\section{Geological Setting}

The Bighorn Basin is a large, intermontane basin in north-central Wyoming and south-central Montana, encompassing an area of nearly $27,000 \mathrm{~km}^{2}$ and bounded by the Bighorn Mountains to the east, the Absaroka Mountains to the west, and the Owl Creek mountains to the south. Anticlines and synclines encircle the basin, with numerous faults and anticlines found along the basin's eastern shoulder, these containing several small oil fields. The center of the basin is composed of Tertiary (Eocene and Paleocene) sediments, while the surrounding shoulder of the basin consists mostly of Cretaceous and Jurassic rock. The area is semi-arid with mean annual rainfall and snowfall of $17.5 \mathrm{~cm}$ and $46 \mathrm{~cm}$, respectively.

A pseudokarst surface containing dolines, blind valleys, and caves is developed on a $150 \mathrm{~m}$ high, $7 \mathrm{~km}$ long ridge on the 78 to $83 \mathrm{Ma}$ late Cretaceous Cody Shale. The area is on U.S. Bureau of Land Management property and is 10 km SE of Greybull, Wyo., in the eastern part of the Bighorn Basin (Fig. 1). Structurally, the area is in a small syncline, between the Torchlight Dome anticline to the west and the Lamb anticline to the east; local dip is $2^{\circ}$ to $5^{\circ} \mathrm{ESE}$ as shown in Figure 2 (Pierce, 1948).

Locally, the Cody Shale is about $1150 \mathrm{~m}$ thick and consists of marine shale, sandstone, and siltstone. The unnamed lower member of the Cody Shale is about $360 \mathrm{~m}$ thick and consists of a dark gray to black, thin-bedded, marine shale, composed of "gray to black shale, calcareous shale, and bentonite, with minor amounts of siltstone and sandstone that were deposited in an offshore environment" (Finn, 2013). Based on the structure contours in Figure 3, drawn on the base of the Cody Shale, the area containing caves is in non-calcareous shales about $100 \mathrm{~m}$ above the base of the Cody Shale.

Soils on the cave ridge are classified as U.S. Department of Agriculture (USDA) soil map unit 371AD, Greybull-Persayo complex, $0-30 \%$ slope. The soil is described as "side slope residuum weathered from shale," consisting of a silty, clay loam for 23 to $28 \mathrm{~cm}$ depth to paralithic bedrock beneath (USDA, 2017). The description of the underlying bedrock as paralithic is consistent with the observed nature of wall material seen in the caves: partially weathered and requiring only a moderate force to be broken into smaller fragments.

While a majority of the dolines and blind valleys are sediment choked, 19 enterable caves, up to $70 \mathrm{~m}$ long, have been observed in nine of 17 drainage basins examined. The caves are found in dolines (Fig. 4) and at the ends of

110701 Pinewalk Way, Highlands Ranch CO 80130, medville@centurylink.net 




Figure 1. Shale cave study area location. blind valleys (Fig. 5). Maps of two of the longer caves are shown in Figures 6 and 7 . The caves are linear, contain stream channels in their floors, and are characterized by gypsum-streaked and gypsum-wedged shale walls. Linear rubble piles, composed of broken and decomposed shale, are found beneath the passage walls.

The caves are developed entirely within the shale, and they have bedrock walls and ceilings covered, in part, by a thin veneer of decomposed shale (clay) as shown in Figure 8. In this image, the arched gray strip across the ceiling is the shale, exposed by removal of the clay coating. Figure 9 illustrates the entrance passage of another cave showing a rubble floor and triangular cross-section.

Enterable caves in non-calcareous shale that contain stream channels in their floors and are not shelters are unusual since dissolution of shale by carbonic or sulfuric acid does not take place in the absence of carbonates. Palmer (2007) states: "Shale does not dissolve perceptibly, but it erodes easily. Its main contribution to speleology is to form shelter caves capped by more resistant rocks." The presence of linear cave passages extending into darkness for distances of up to $70 \mathrm{~m}$ (Figs. 6 and 7) appears to be unusual and resulted in this investigation.

\section{Methods}

Bulk mineral analysis of cave wall material was conducted using a Pananalytical X'Pert Pro $X$-Ray Diffraction (XRD) diffractometer for powder XRD analysis. Continuous scans over a 40-minute period were carried out between $6^{\circ}$ and $69^{\circ} 2 \theta$ positions with a step size of $0.017^{\circ}$. Counting peaks provided a semi-quantitative measure of mineral components in the sam-

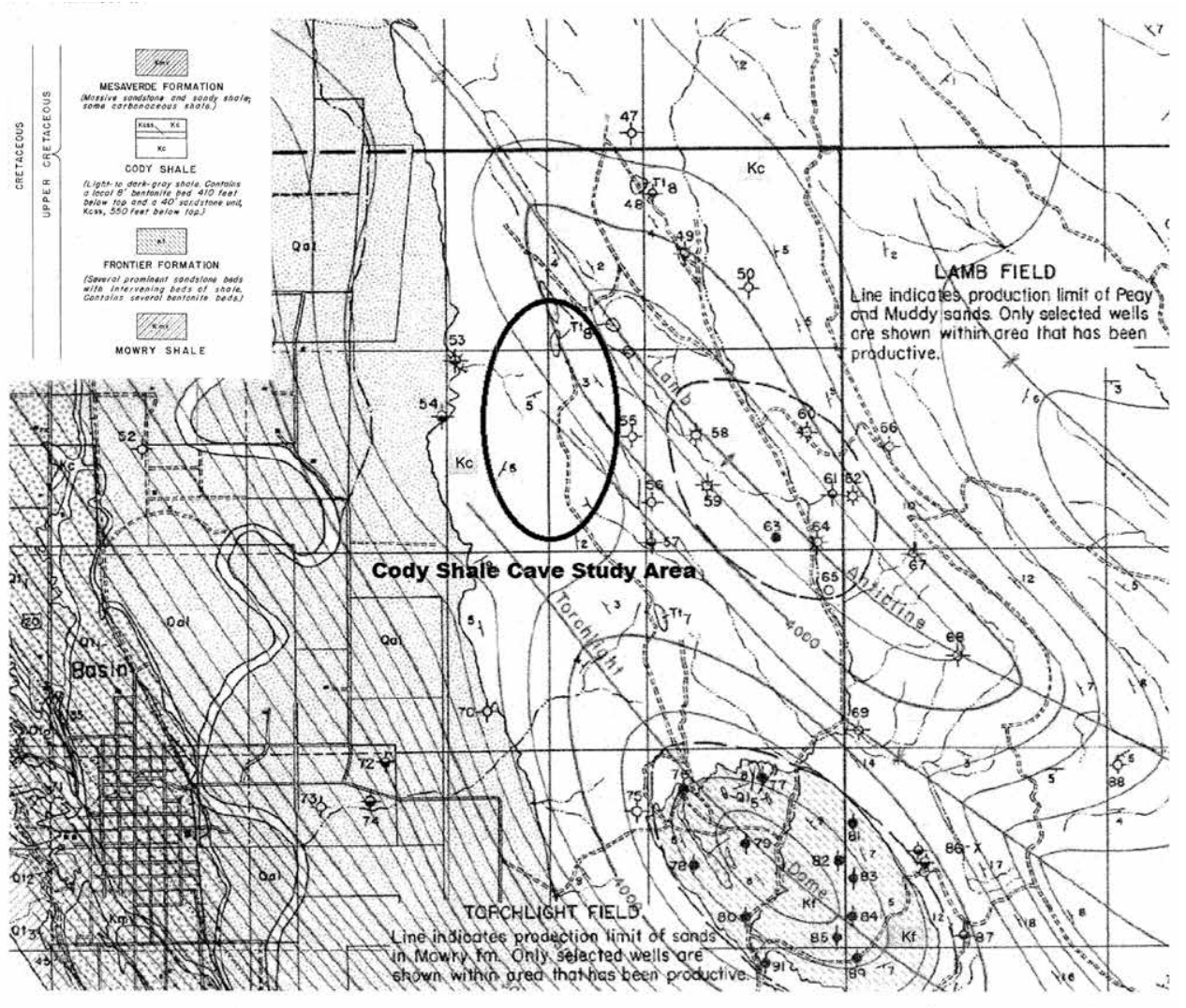

Figure 2. Structure contour map of study area. Contours on base of Cody Shale/top of the Frontier Formation. 


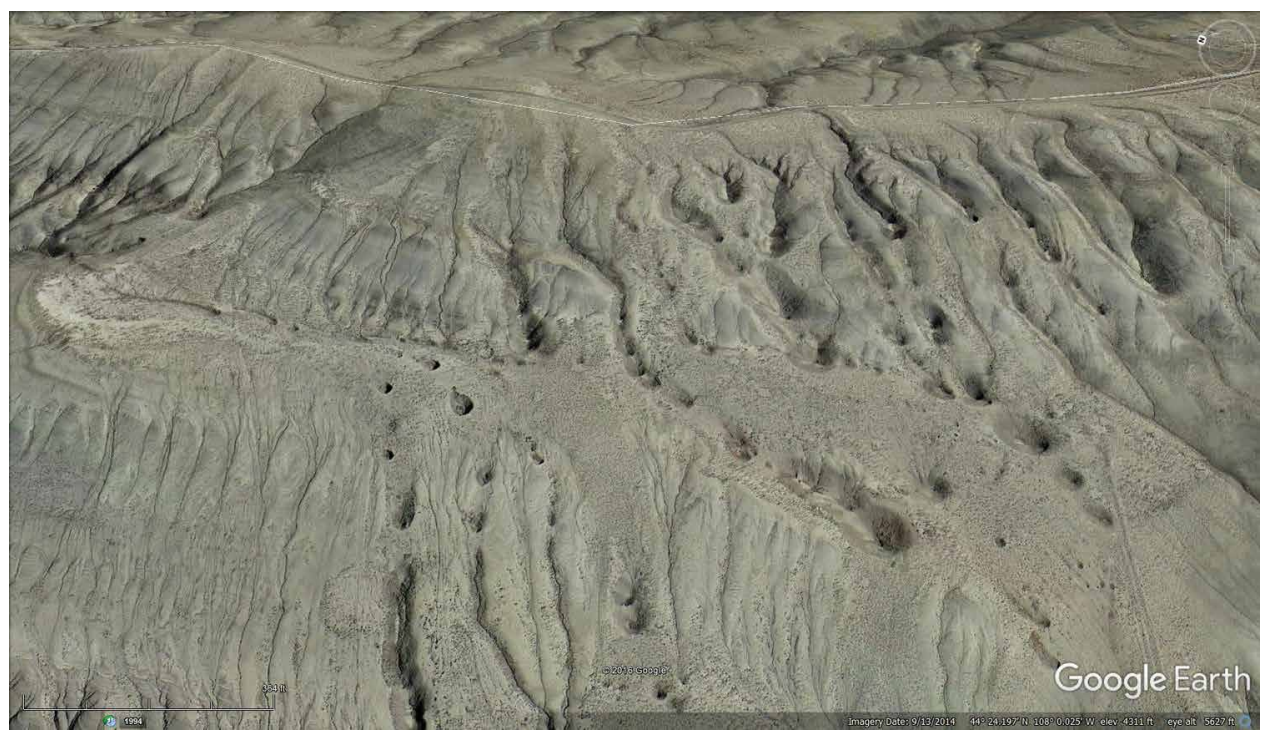

Figure 3. Cody Shale pseudokarst east of Basin, Wyoming.

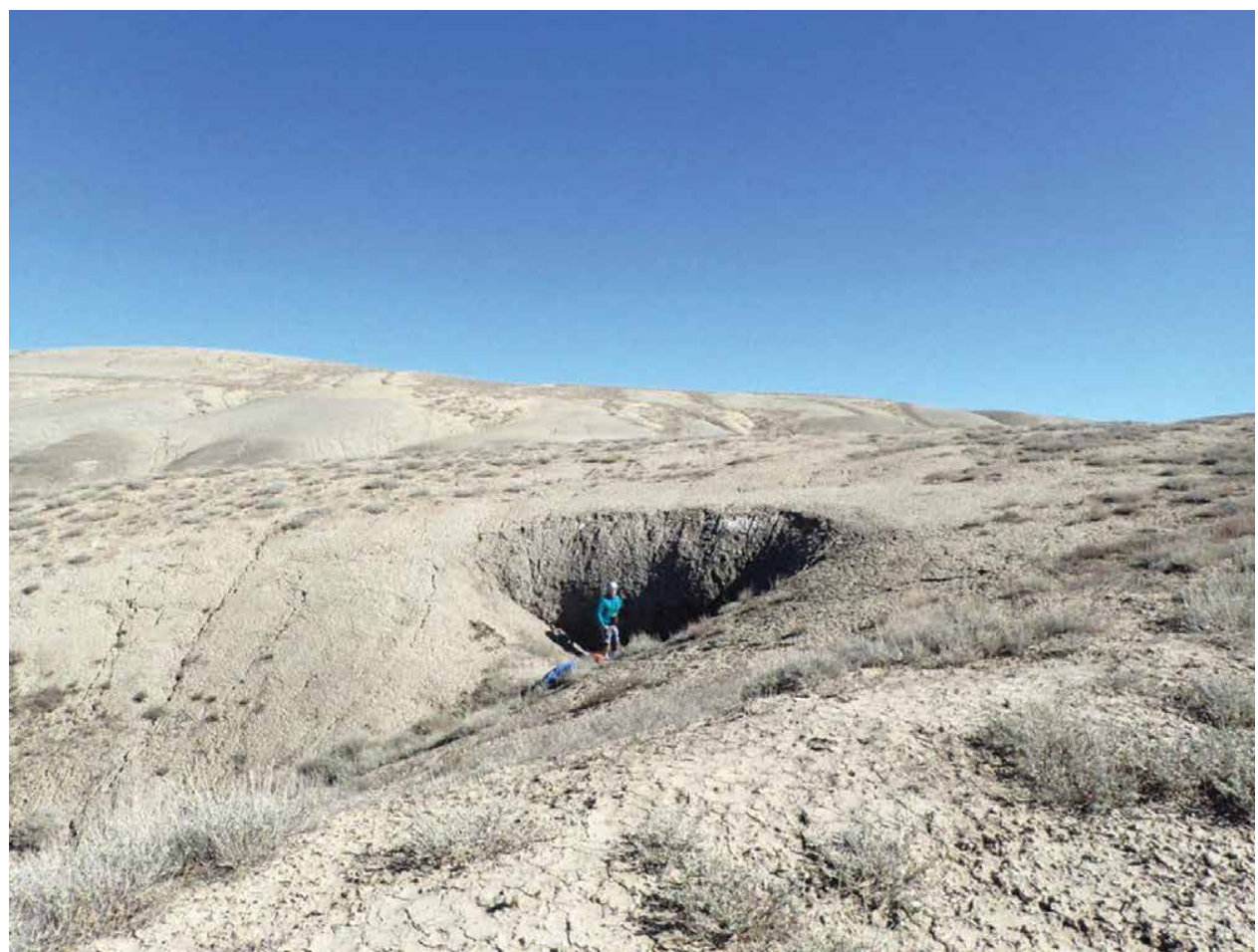

Figure 4. Cave entrance in doline on weathered Cody Shale. ples with peak intensities, which were used to determine the relative mineral proportions.

Scanning electron microscopy (SEM), using a Tescan Vega 3 SEM coupled with an IXRF Systems silicon drift $X$-ray detector (XRD) for elemental analysis, was applied to examine gypsum, framboidal pyrite pseudomorphs, and biofilms found on the shale at $5 \mu \mathrm{m}-10 \mu \mathrm{m}$ scales. X-ray counting peaks on Energy Dispersive Spectroscopy (EDX), results were consistent with those seen in XRD diffractograms for minerals of interest: gypsum and goethite. Stable sulfur isotope measurements were conducted using a Costech Instruments Elemental Analyzer (CHNS-O ECS 4010) coupled to an Isochrom Continuous Flow Stable Isotope Ratio Mass spectrometer. $\delta^{34} S$ results, with respect to the Canyon Diablo Troilite meteorite standard, were reported in per mil (\%o) units.

\section{Process Initiation}

As noted, the surface above the caves contains blind valleys, entrances, pits, and dolines. These features are the same as those found in karst terranes, but the processes involved differ: corrasional removal of study area material versus carbonate rock dissolution.

Soil samples were taken at cave entrances and from the cave floor and sent to the Soil Testing Laboratory at Colorado State University. These samples were analyzed for three measures of the soil propensity to swell, and by inference, to allow surface water to move downward reaching the unweathered shale. Tests were conducted to determine the exchangeable sodium percentage (ESP), the sodium adsorption ratio (SAR), and the soil's cation exchange capacity (CEC), a measure of the ability of wetted cations, adsorbed on clay surfaces, to be exchanged with other cations.

ESP (i.e., the percentage of cations that are sodium) was $8.4 \%$, lower than the $15 \%$ expected for sodic soils (Parker and Higgins, 1990). SAR, defined as $\mathrm{Na} /[0.5(\mathrm{Ca}+\mathrm{Na})]^{1 / 2}$, another measure of sodicity, is an indicator of the soil's susceptibility to develop pipes. For the samples tested, SAR was $7.3 \mathrm{meq} / \mathrm{L}$, slightly higher than the minimum of 5.0 meq/L expected for soils subjected to piping failure (Parker and Higgins, 1990). Finally, CEC, determined by measuring the ratio of each cation quantity to that cation's equivalent weight, summing the ratios, and converting the result to meq/100g, was 17.6 . The range of CECs for sodium montmorillonite is 60 to $150 \mathrm{meq} / 100 \mathrm{~g}$ (Carroll, 1959; Soil Quality Organization, 2017), substantially higher than the mean CEC for the soil samples tested, since the montmo- 


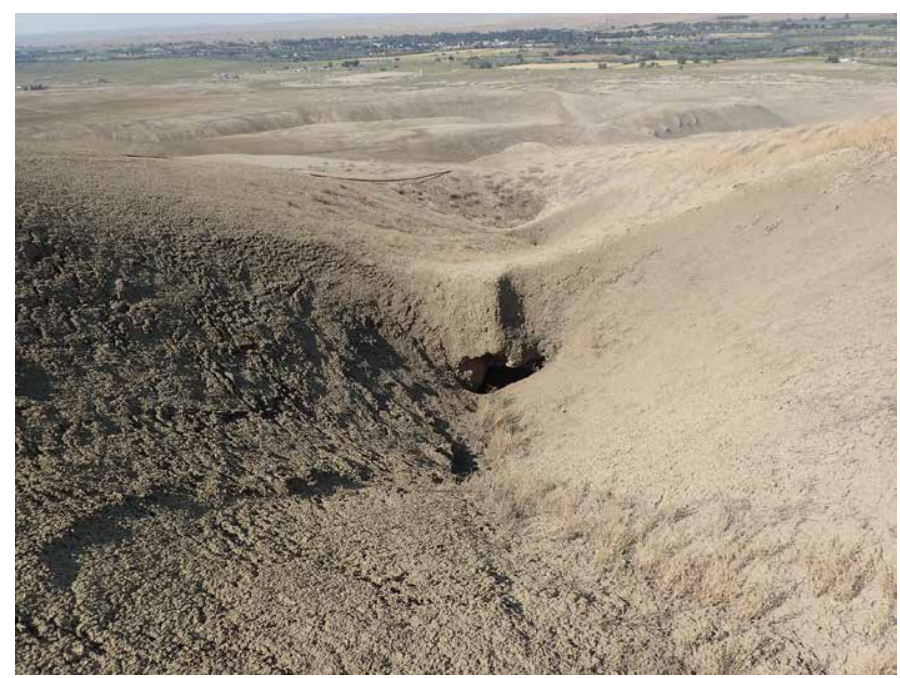

Figure 5. Entrance at the lower end of a blind valley.

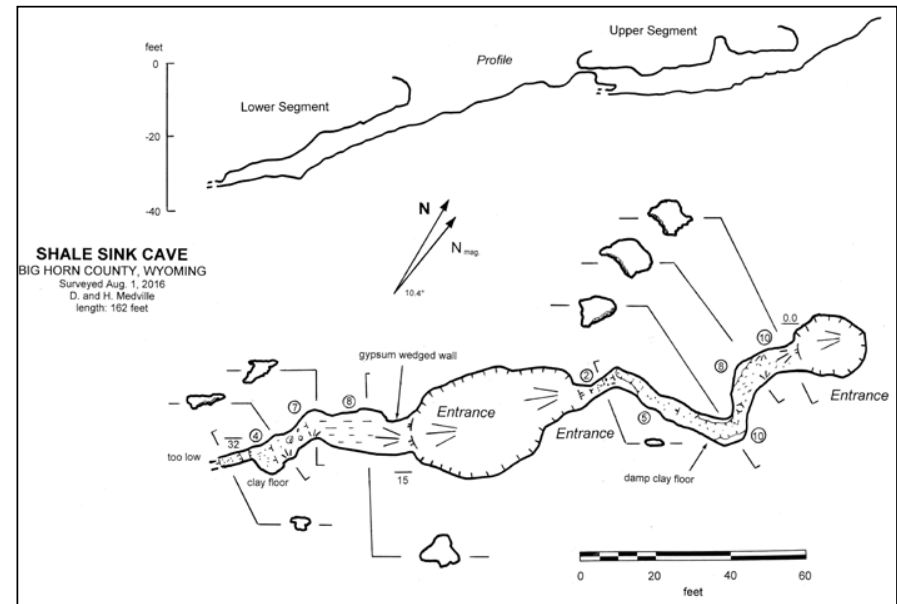

Figure 6. Segmented cave in shale.

rillonite content of the eroded shale at cave entrances is only on the order of $15 \%$ to $20 \%$. Consequently, the CEC for this material should be correspondingly lower than for soils having a higher concentration of montmorillonite. For samples of the Cretaceous Mancos Shale in western Colorado that contain similar quantities (20 to $40 \mathrm{meq} / 100 \mathrm{~g}$ ) of smectite-family clays, "the cation exchange capacity of weathered Mancos Shale samples ranged from 13.14 to $25.15 \mathrm{meq} / \mathrm{g}$ " (U.S. Department of Energy, 2011), consistent with the $17.6 \mathrm{meq} / 100 \mathrm{~g}$ value obtained for the eroded Cody Shale sample.

The tests indicate that the weathered Cody Shale on the surface above the caves has a modest swell potential since the mean montmorillonite content in the two shale samples from cave walls was only $17 \%$. However, this is an amount sufficient to allow soil swell/shrink cycles to take place and to produce the landforms observed. The resulting openings provide a means for oxygen to reach the shale. Water can also reach the shale through normal fluvial processes (erosion and deepening of gullies) and via inter-pore vertical movement through the regolith. Downward diffusion of reactive $\mathrm{O}_{2}$, carried in solution by water moving through the unsaturated zone in the shale, results in the oxidation of pyrite in the shale.

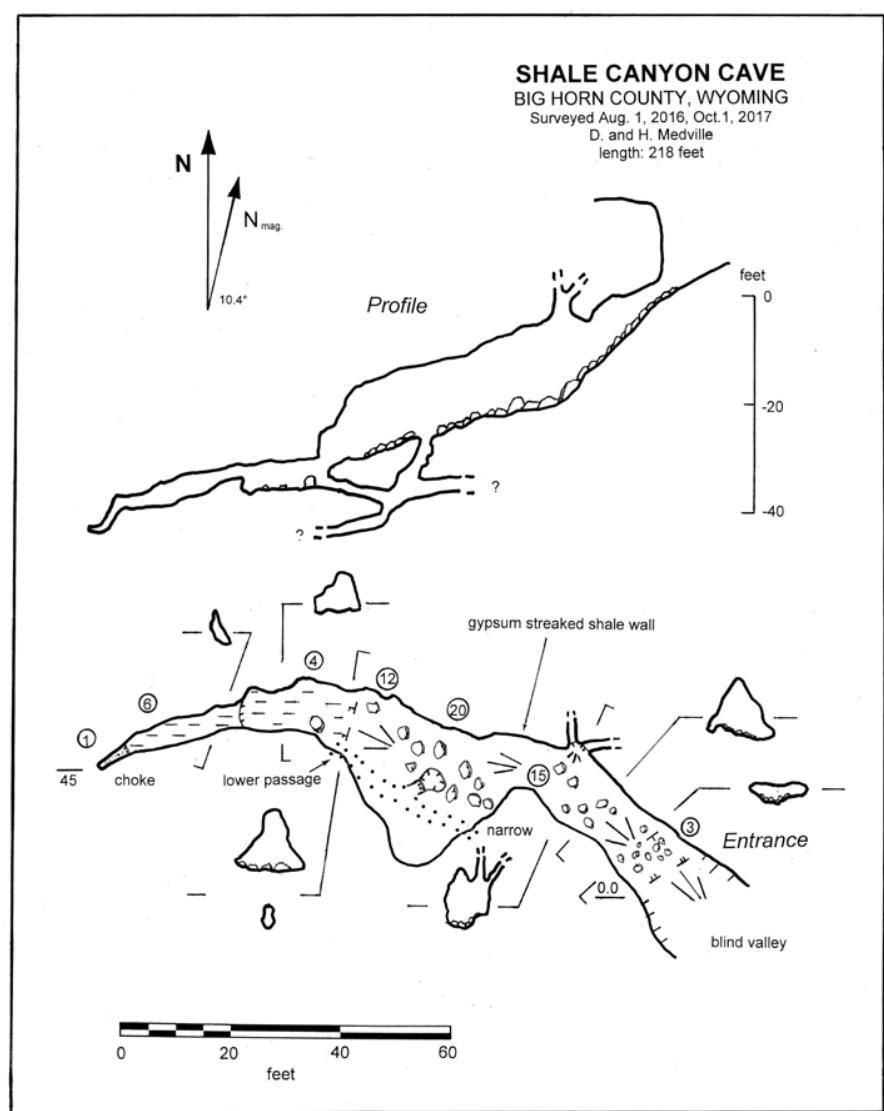

Figure 7. Cave below blind valley.

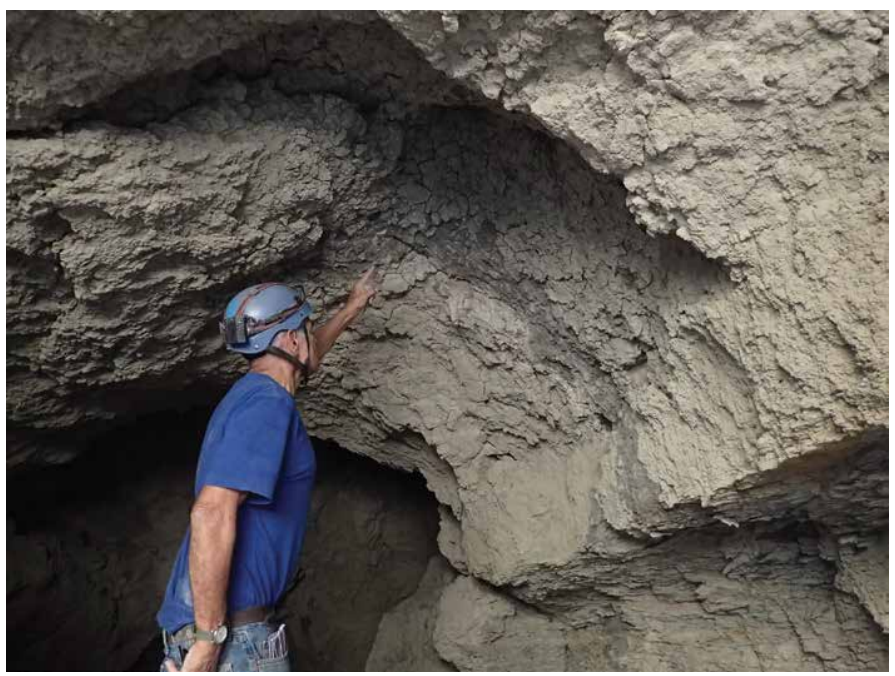

Figure 8. Ceiling of a cave in the Cody Shale showing exposed shale. 


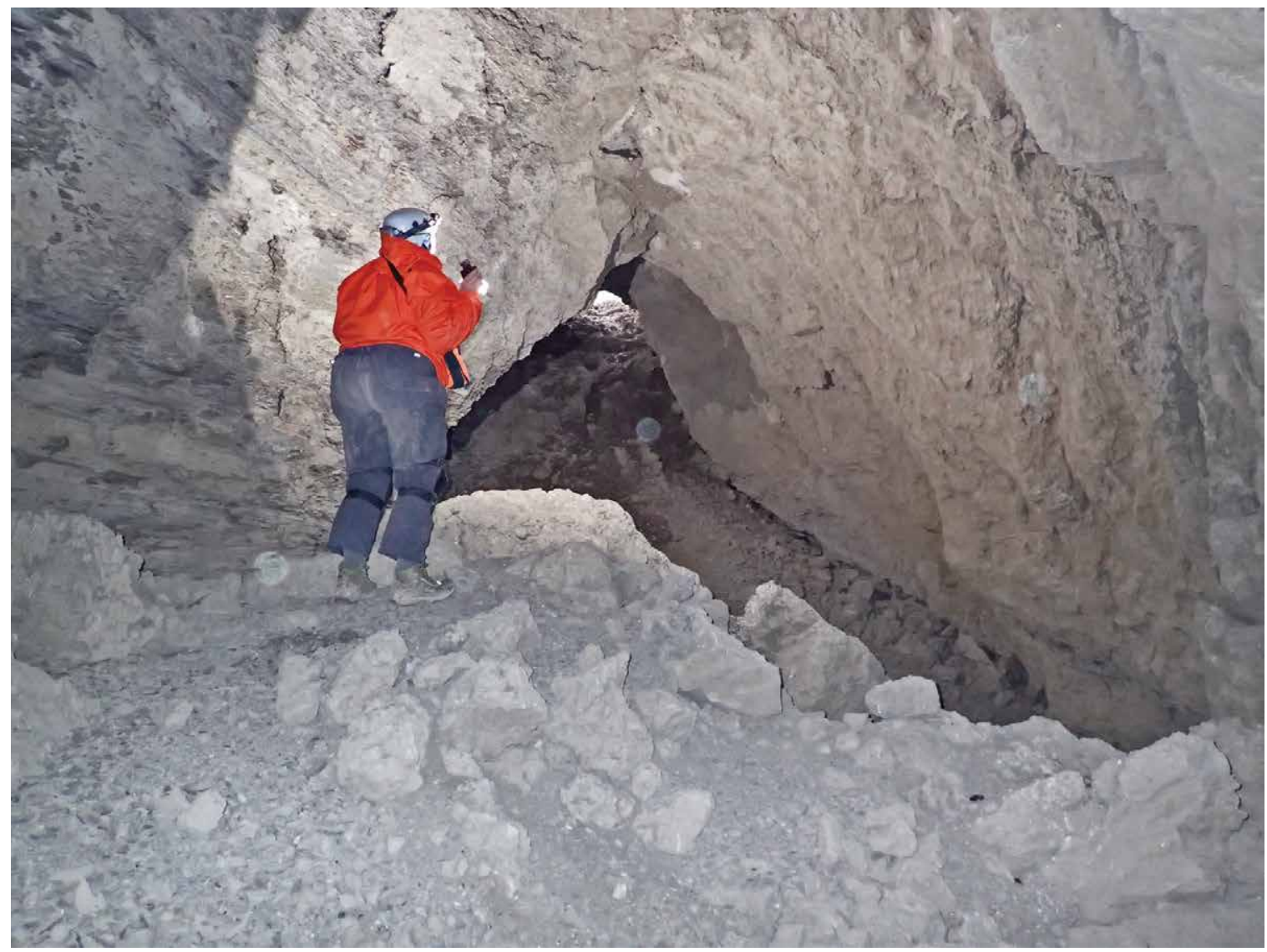

Figure 9. Passage cross-section showing rubble floor.

Table 1. Composition of wall material in shale caves.

\begin{tabular}{cccc}
\hline Location & Quartz, \% & Muscovite, \% & $\begin{array}{r}\text { Montmorillonite } \\
\text { and Kaolinite, \% }\end{array}$ \\
\hline Shale Sink Cave, upper segment & 35 & 41 & 21 \\
Shale Sink Cave, lower segment & 44 & 37 & 17 \\
Shale Canyon Cave & 34 & 42 & 20 \\
\hline
\end{tabular}

\section{Shale Composition}

Samples of the wall material were taken in three of the caves and sent to the New Mexico Bureau of Geology for a bulk mineral analysis using powder X-Ray diffraction. The composition of the wall samples is shown in Table 1.

The composition for the samples is nearly the same: predominantly quartz and muscovite (mica) with moderate quantities of montmorillonite and kaolinite. Remaining material consisted of minor quantities of dolomite and gypsum (1 $\%$ to $3 \%$ of each). Calcite, if present, was below detection limits of $2 \%$ by weight. Sodium montmorillonite, a swelling, smectite-family clay in the shales sampled, is the primary constituent of bentonite, a swelling clay that is mined locally from beds in the Cody Shale. The presence of montmorillonite in the shale is consistent with the pseudokarst surface observed above the caves: desiccation cracks, a popcorn-like surface on the soil, small pits, dolines, and blind valleys as illustrated in Figures 4 and 5.

\section{Pyrite Oxidation}

A variety of well-documented, pyrite weathering pathways exist (Penner, et al., 1972; Hoover, et al., 2004). Under aerobic conditions, the chemolithoautotrophic bacterium $A$. ferrooxidans uses pyrite $\left(\mathrm{FeS}_{2}\right)$ as an electron donor and oxidizes it into ferric iron and sulfuric acid. This takes place in two steps as per reactions (1) and (2) below.

Oxidation of iron sulfide to ferrous sulfate and sulfuric acid:

$$
2 \mathrm{FeS}_{2}+2 \mathrm{H}_{2} \mathrm{O}+7 \mathrm{O}_{2} \rightarrow 2 \mathrm{FeSO}_{4}+2 \mathrm{H}_{2} \mathrm{SO}_{4}
$$

followed by conversion from ferrous to ferric sulfate, where the bacteria increase the ferrous oxidation rate by five to six orders of magnitude "and thereby makes pyrite oxidation a rapid self-perpetuating process" (Nordstrom, 1982) 

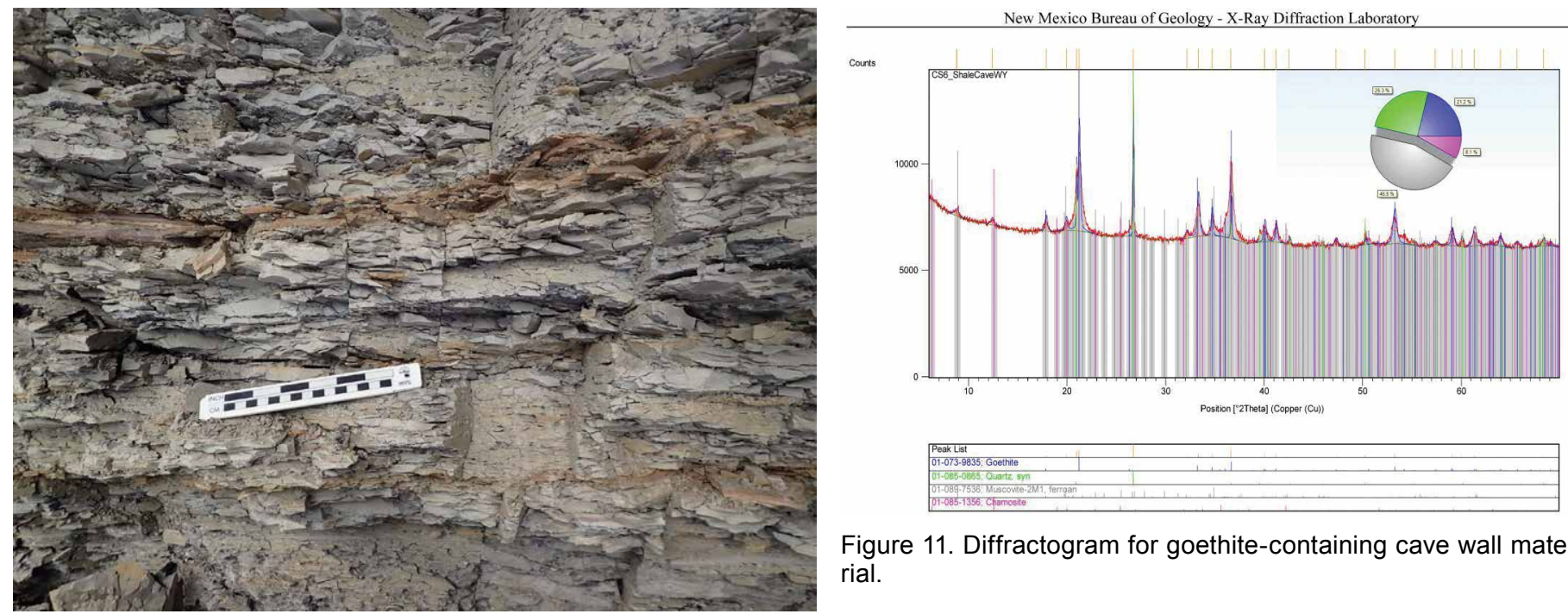

Figure 11. Diffractogram for goethite-containing cave wall material.

Figure 10. Tan beds containing goethite in cave wall. Length of scale bar is $15 \mathrm{~cm}$.

$$
4 \mathrm{FeSO}_{4}+\mathrm{O}_{2}+2 \mathrm{H}_{2} \mathrm{SO}_{4} \rightarrow 2 \mathrm{Fe}_{2}\left(\mathrm{SO}_{4}\right)_{3}+2 \mathrm{H}_{2} \mathrm{O}
$$

For low pH (e.g., $\leq 3)$ this is followed by the reaction of ferric sulfate with additional, unreacted pyrite, to yield additional ferrous sulfate and sulfuric acid:

$$
7 \mathrm{Fe}_{2}\left(\mathrm{SO}_{4}\right)_{3}+\mathrm{FeS}_{2}+8 \mathrm{H}_{2} \mathrm{O} \rightarrow 15 \mathrm{FeSO}_{4}+8 \mathrm{H}_{2} \mathrm{SO}_{4}
$$

As the $\mathrm{pH}$ increases above 3 , solids will precipitate and the reaction is

$$
\mathrm{Fe}_{2}\left(\mathrm{SO}_{4}\right)_{3}+6 \mathrm{H}_{2} \mathrm{O} \rightarrow 2 \mathrm{Fe}(\mathrm{OH})_{3}+3 \mathrm{H}_{2} \mathrm{SO}_{4}
$$

yielding ferric hydroxide and sulfuric acid. ${ }^{2}$ The dehydration of the ferric hydroxide yields goethite, a solid ferric oxyhydroxide, resulting from the oxidation of iron-rich sulfide minerals,

$$
\mathrm{Fe}(\mathrm{OH})_{3} \rightarrow \mathrm{FeO}(\mathrm{OH})+\mathrm{H}_{2} \mathrm{O}
$$

A summary reaction for pyrite oxidation, skipping the intermediate steps, with goethite and sulfuric acid as reaction products, is given in Taylor and Eggleton, (2001):

$$
4 \mathrm{FeS}_{2}+15 \mathrm{O}_{2}+10 \mathrm{H}_{2} \mathrm{O} \rightarrow 4 \mathrm{FeO}(\mathrm{OH})+8 \mathrm{H}_{2} \mathrm{SO}_{4}
$$

Macroscopic evidence for goethite as a reaction product is provided by thin stringers and small masses of a yellow-tan material, observed on the shale cave walls, as illustrated in Fig. 10. X-Ray diffraction of a sample of this material indicates that a majority $(71 \%)$ of the material is quartz and muscovite (mica), and a substantial component $(21.2 \%)$ is goethite (Fig. 11). The $2 \theta$ peaks at $21^{\circ}, 33^{\circ}, 36^{\circ}$, and $41^{\circ}$ are those seen in diffractograms for pure goethite (RRUFF database, 2017).

A graphic summary of the overall sequence of reactions for microbially-assisted pyrite oxidation, resulting in sulfate ions and goethite, is shown in Figure 12, and is reproduced from figure 3 in Nordstrom (1982) with the reaction pathway highlighted. Nordstrom describes this figure as "the grand sequence of reactants, products, and catalysts for pyrite oxidation." Note that in 2000, T. ferrooxidans, referred to in Figure 12, was reclassified as Acidithiobaccillus ferrooxidans (Kelly and Wood, 2000) and the A. ferrooxidans genus/species terminology is used in this paper.

\section{Conversion to Gypsum}

Sulfuric acid resulting from pyrite oxidation will react with calcite in the shale to produce gypsum, water, and $\mathrm{CO} 2$, with one mole of calcite being replaced by one mole of gypsum:

$$
\mathrm{CaCO}_{3}+\mathrm{H}_{2} \mathrm{SO}_{4}+2 \mathrm{H}_{2} \mathrm{O} \rightarrow \mathrm{CaSO}_{4} \cdot 2 \mathrm{H}_{2} \mathrm{O}+\mathrm{H}_{2} \mathrm{O}+\mathrm{CO}_{2}
$$

Evidence for pyrite-derived gypsum deposition in the Cody Shale caves is provided by the presence of numerous fibrous, gypsum fracture fillings, 1 to $3 \mathrm{~cm}$ thick, observed on cave walls (Fig. 13). This is consistent with the obser-

\footnotetext{
${ }^{2}$ Other reactions that yield sulfuric acid, sulfate ions, and ferric hydroxide from pyrite oxidation are:

$4 \mathrm{FeS}_{2}+14 \mathrm{H}_{2} \mathrm{O}+15 \mathrm{O}_{2} \rightarrow 4 \mathrm{Fe}(\mathrm{OH})_{3}+16 \mathrm{H}^{+}+8 \mathrm{SO}_{4}^{+}$

$\mathrm{FeS}_{2}+15 / 4 \mathrm{O}_{2}+7 / 2 \mathrm{H}_{2} \mathrm{O} \rightarrow \mathrm{Fe}(\mathrm{OH})_{3}+2 \mathrm{H}_{2} \mathrm{SO}_{4}$
} 


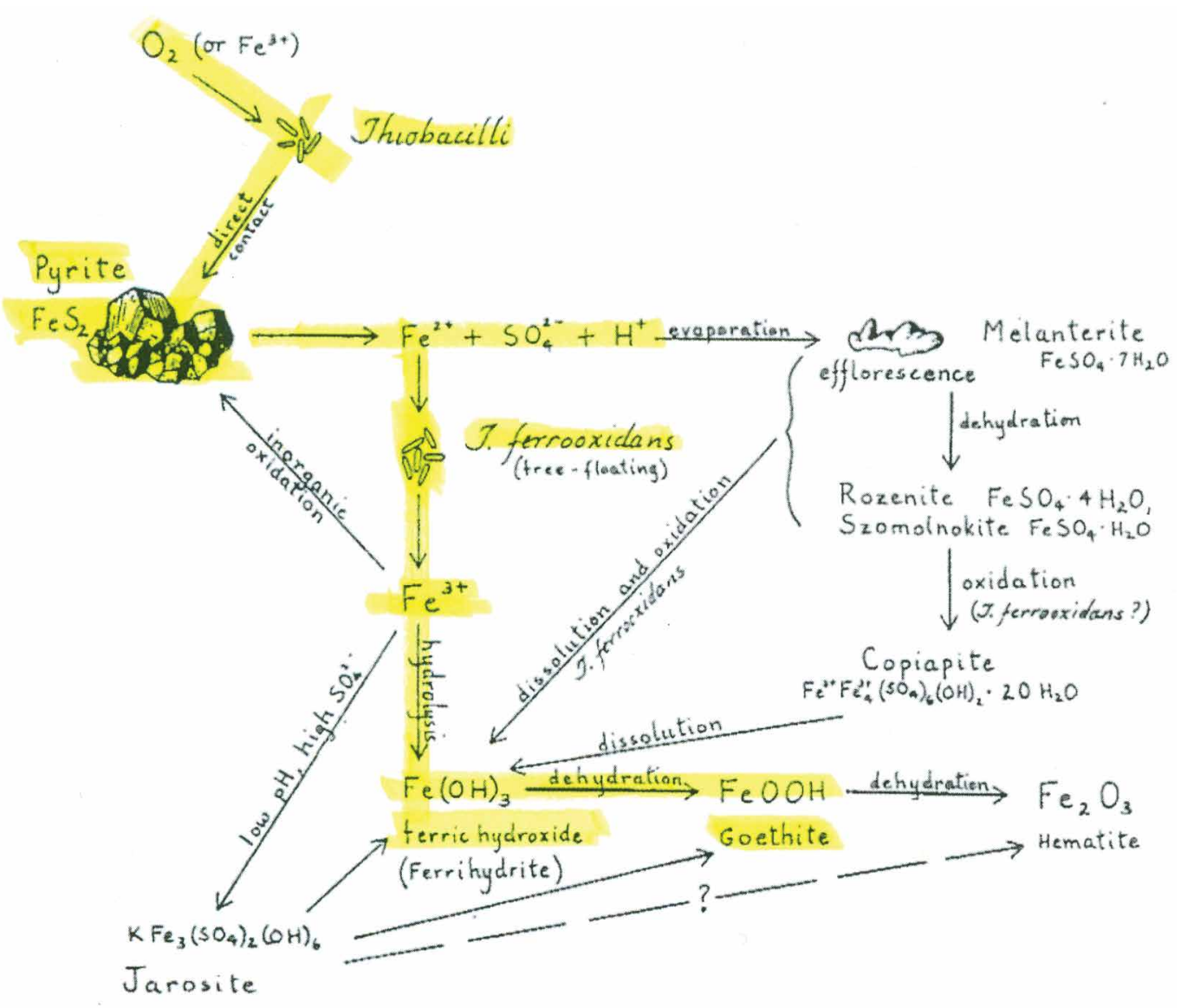

Figure 12. Summary of pyrite oxidation reactions (from Nordstrom, 1982)

Fig. 3. The overall sequence of mineral reactions for pyrite oxidation showing the relationships between oxidizing agents, catalysts, and mineral products.

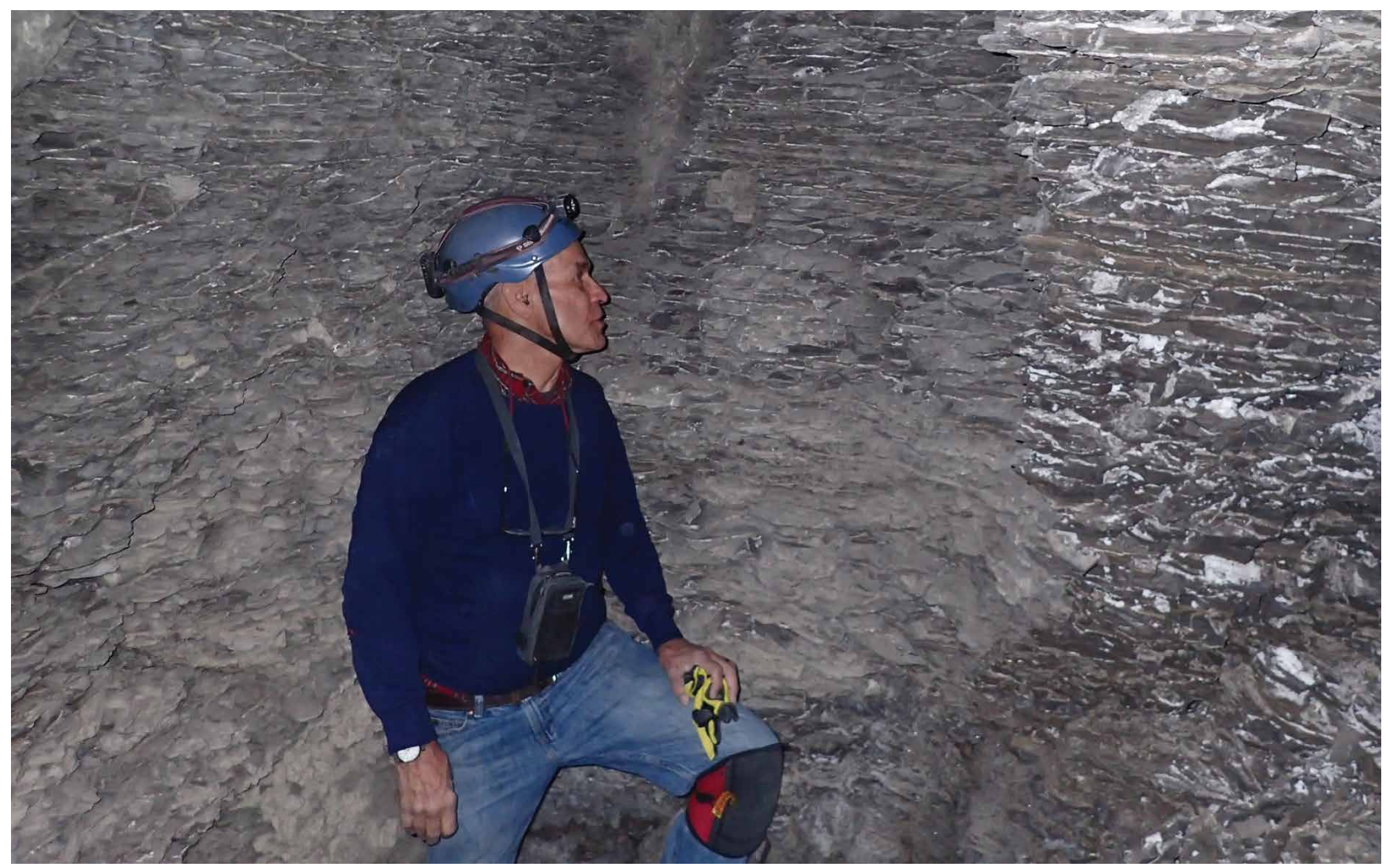

Figure 13. Gypsum fracture fillings in passage wall. 
vation that pyrite oxidation is local, and that the resulting gypsum commonly concentrates along certain beds or bedding-plane partings (Palmer, 2007).

The concentrated gypsum fracture fillings observed between layers in the shale, i.e., crystallization in bedding plane partings, as illustrated in Figures 13 and 14, is consistent with a pyrite oxidation source of sulfate ions, resulting in replacement of calcite by gypsum. Other evidence for pyrite as a source, e.g., halos of gypsum around oxidized pyrite grains and staining of the gypsum by iron oxides, has not been observed, however.

The source of the sulfur in the gypsum can be determined via stable sulfur isotope analysis by computing the deviation of the ${ }^{34} \mathrm{~S} /{ }^{32} \mathrm{~S}$ isotope ratio from the standard ratio of 0.045005 , obtained from troilite in the Canyon Diablo meteorite (Thode, 1991).

$$
\delta^{34} \mathrm{~S}=1000 \times\left[\left({ }^{34} \mathrm{~S} /{ }^{32} \mathrm{~S}\right)_{\text {sample }} /\left({ }^{34} \mathrm{~S} /{ }^{32} \mathrm{~S}\right)_{\text {standard }}-1\right] \%
$$

Three potential sources of sulfur exist:

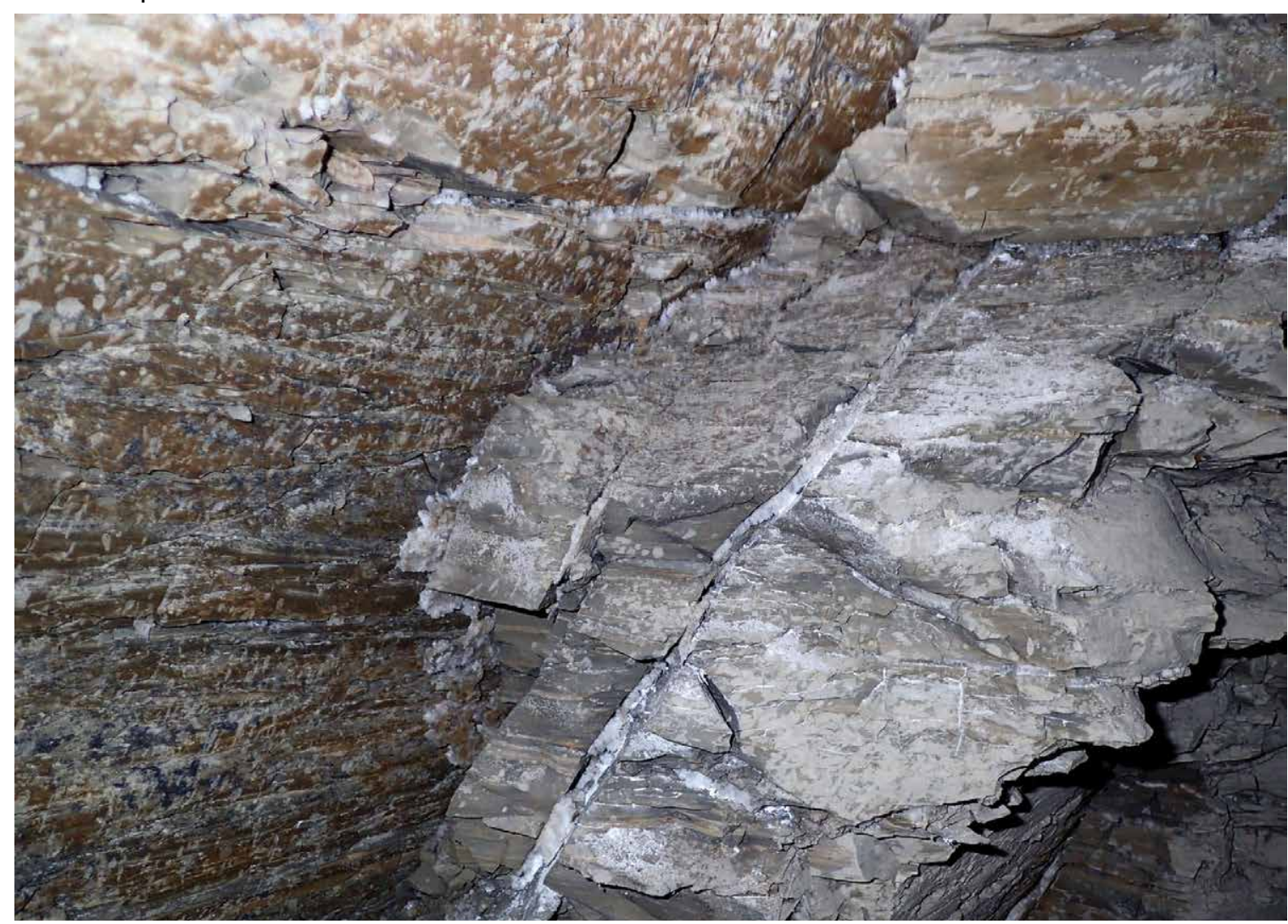

Figure 14. Shale wall (left) with gypsum-wedged shale (right). Height and width are about $1 \mathrm{~m}$. (a) $\mathrm{H} 2 \mathrm{~S}$ from petroleum. The area containing the caves is 3 $\mathrm{km} \mathrm{NW}$ of an active oil and gas field (Torchlight Dome). However, production is from Cretaceous sands, $152 \mathrm{~m}$ to $305 \mathrm{~m}(500 \mathrm{ft}$ to $1000 \mathrm{ft}$ ) below the caves, with no $\mathrm{H} 2 \mathrm{~S}$ reported (Lupton, 1916). If petroleum is the source of the sulfur, $\delta^{34} S$ deviations on the order of 0 to $+30 \%$ may be expected. (b) Gypsum precipitated from sea water during deposition of the Cody Shale; i.e., ancient marine gypsum. Seawater sulfate from the Cretaceous is enriched in ${ }^{34} \mathrm{~S}$ with respect to the standard. Positive $\delta^{34} S$ values of $19.0 \%$ to $19.5 \%$ were reported for Cretaceous seawater at $\approx 80$ Ma (Paytan, A. et al., 2011); i.e., at the midpoint of the 78 to $83 \mathrm{Ma}$ age range for the Cody Shale.

(c) Gypsum derived from pyrite. This gypsum will be light in ${ }^{34} \mathrm{~S}$ with negative $\delta^{34} S$ values expected. For example, White (2015) states that deviations on the order of -1 to -5 "are in the range expected if the sulfur in the gypsum is derived from the oxidation of pyrite." Also, highly negative $\delta^{34} \mathrm{~S}$, compared to

Figure 15. Shale containing gypsum fracture fillings and goethite laminations. 


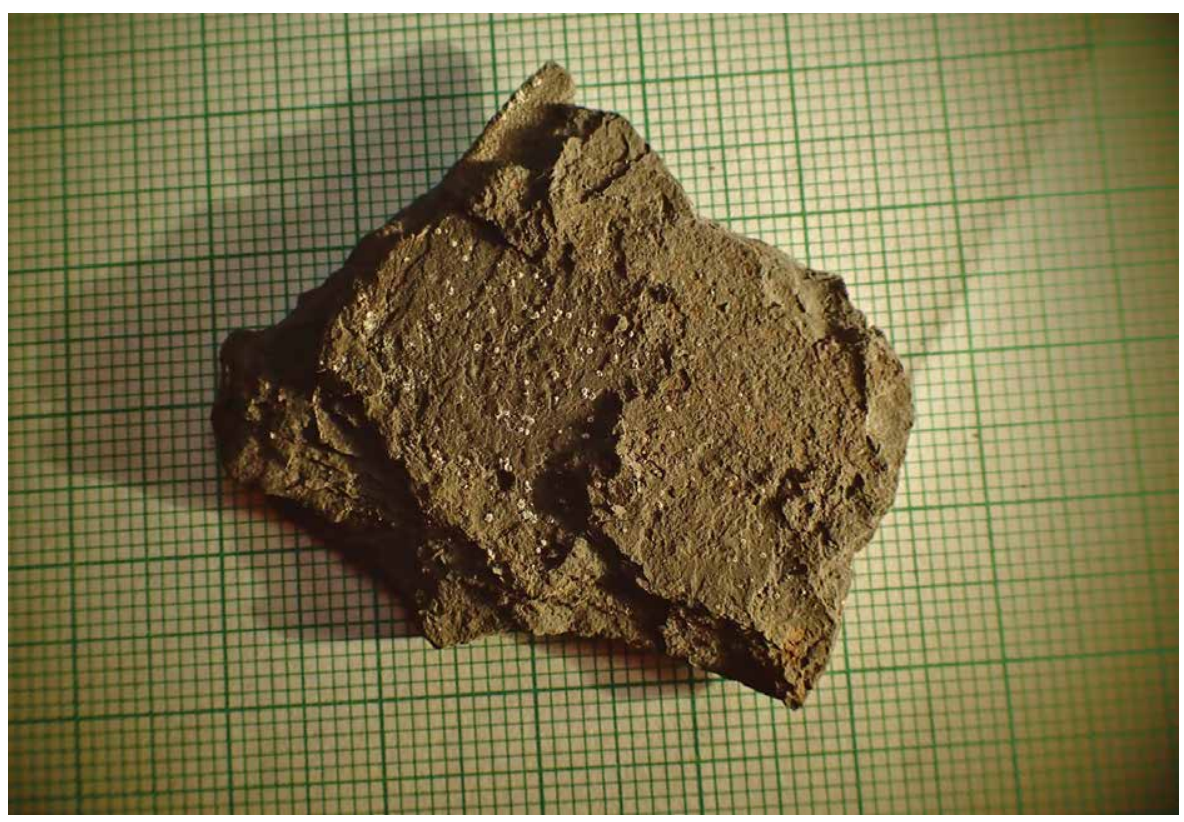

Figure 16. Gypsum inclusions on shale surface, $1 \mathrm{~mm}$ background grid.

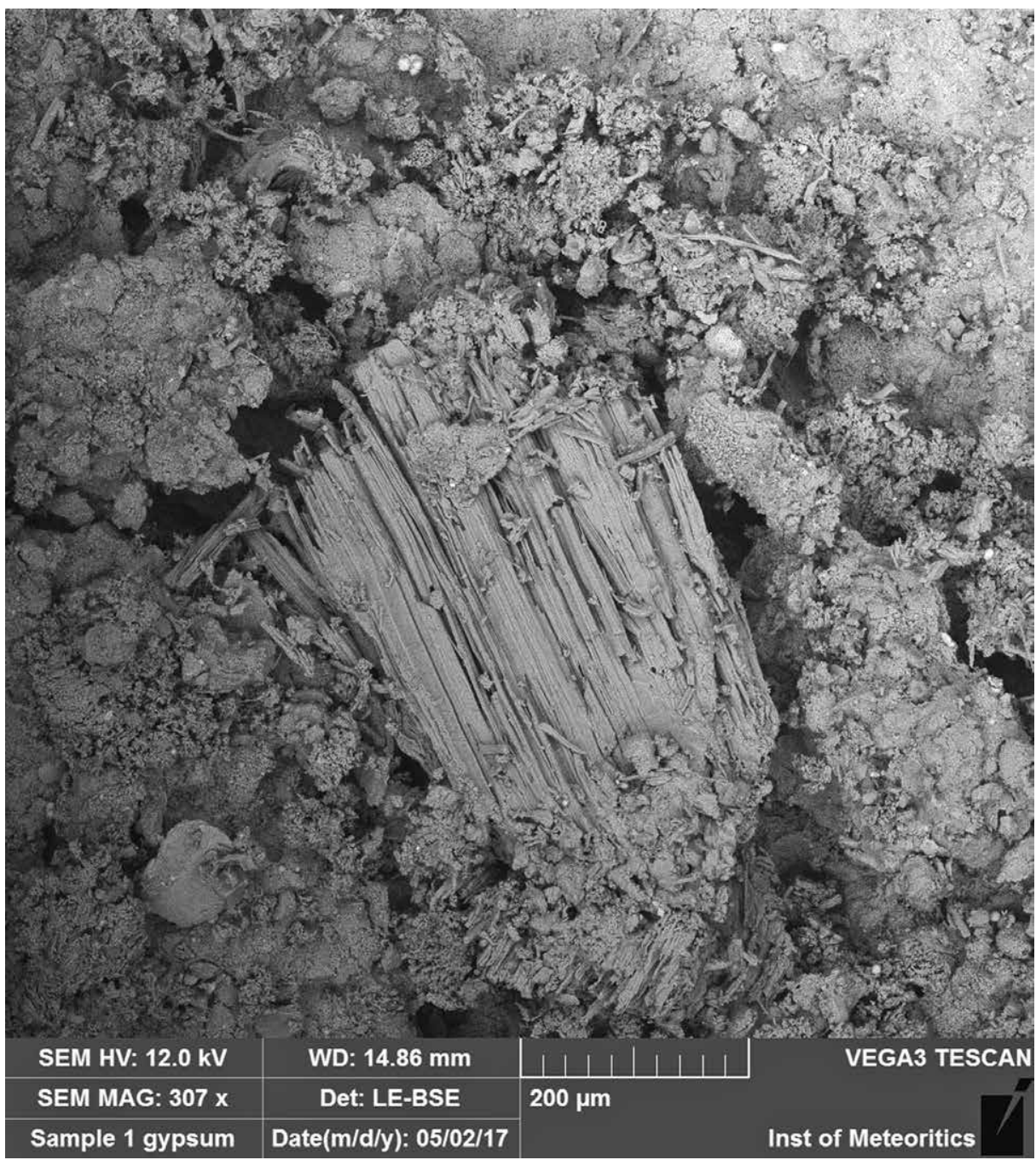

Figure 17. SEM image of gypsum on shale.
Permian-age gypsum beds in Carlsbad Cavern, is cited as evidence for the sulfur not being derived from marine gypsum (Palmer, 2007).

To determine the origin of the sulfur in the gypsum, samples were removed from fracture fillings in the walls of two caves, about $0.5 \mathrm{~km}$ apart. The samples were finely ground, and $50 \mathrm{mg}$ of each sample was sent to the Environmental Isotope Laboratory at the University of Waterloo in Ontario, Canada for sulfur isotope analysis. Measured $\delta^{34} S$ values of $-12.65 \%$ for one sample and -8.11 $\%$ for the other were obtained, supporting the hypothesis that the sulfur in the gypsum samples was derived from pyrite. Pyrite was not detected in the shale or clay (eroded shale) samples analyzed via XRD. It either exists, but the quantities are below the limits of detection ( $1 \%$ by weight), or, for the samples taken, all of the pyrite has been oxidized and is no longer present.

The hypothesis that all of the pyrite, and also all of the calcite in the shale, has been depleted is supported in a paper that analyzed the influence of weathering on pyrite oxidation and carbonate dissolution of a Silurian Shale in Pennsylvania as a function of depth beneath the regolith (Brantley, et al., 2013). Based on drill borings, the study proposed that the observed absence of carbonates and pyrite in fractured shale above the water table was a result of pyrite oxidation and carbonate dissolution reaction fronts in the shale by $\mathrm{CO}_{2}$-charged fluids and $\mathrm{H}_{2} \mathrm{SO}_{4}$. The paper concluded that "Pyrite and carbonate depletion go to 100 $\%$ completion because the mineral abundances are generally low and the reactions fast relative to physical erosion of material; in contrast, clay mineral depletion is not complete at the land surface because clays are abundant and weathering rates are slow." This conclusion is consistent with the lack of detectable quantities of both pyrite and calcite in the shale wall samples taken for XRD analysis. However, the possibility exists that pyrite oxidation alteration products (i.e., pseudomorphs) may still exist in 


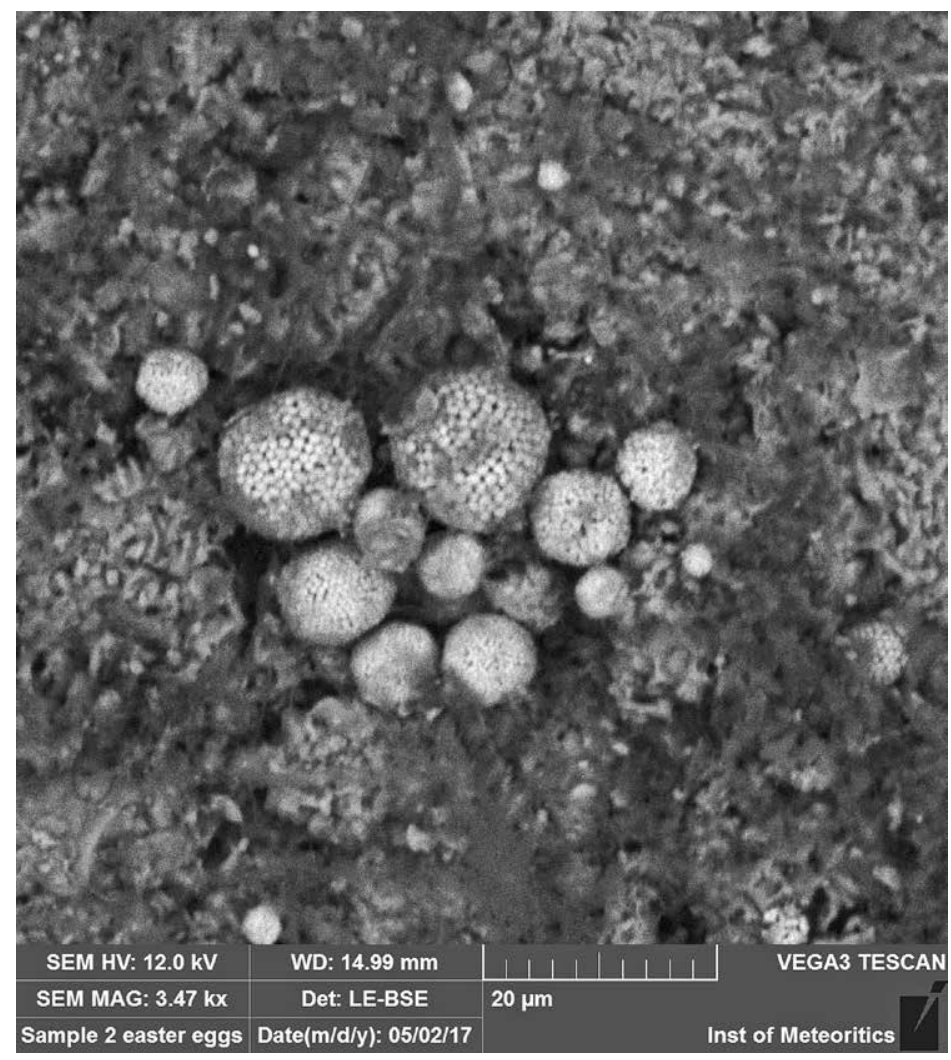

Figure 18. Framboidal pyrite pseudomorphs on shale surface.

the shale.

\section{Microbial Influence on Pyrite Depletion and Re- placement}

To determine whether any pyrite or its reaction products still exist, samples of shale, observed to contain sub-mm scale, round, white inclusions, hypothesized to be starburst gypsum, were taken from the passage walls (Fig. 16) and separated into individual shale platelets.

The shale samples were analyzed at the Electron Microprobe and Scanning Electron Microscope Laboratories at the University of New Mexico using SEM imaging of the samples, coupled with energy dispersive spectroscopy (EDS) to identify the elemental composition of the constituents. As expected, the white inclusions were identified as gypsum (Fig. 17), with high-counting peaks for $\mathrm{O}, \mathrm{S}$, and $\mathrm{Ca}$ observed on the EDS results. In addition, framboidal pyrite pseudomorphs were also observed (Fig. 18). Results of the analysis of the elemental composition of the pseudomorphs, using EDS, are shown in Figure 19 with high-counting peaks for $O$ and $\mathrm{Fe}$, consistent with bacteria metabolizing the sulfur in the pyrite. The $\mathrm{Fe}$ is present as an oxyhydroxide, most likely goethite: $\mathrm{FeO}(\mathrm{OH})$, consistent with the brown deposits observed on passage walls (Fig. 10) and confirmed by XRD.

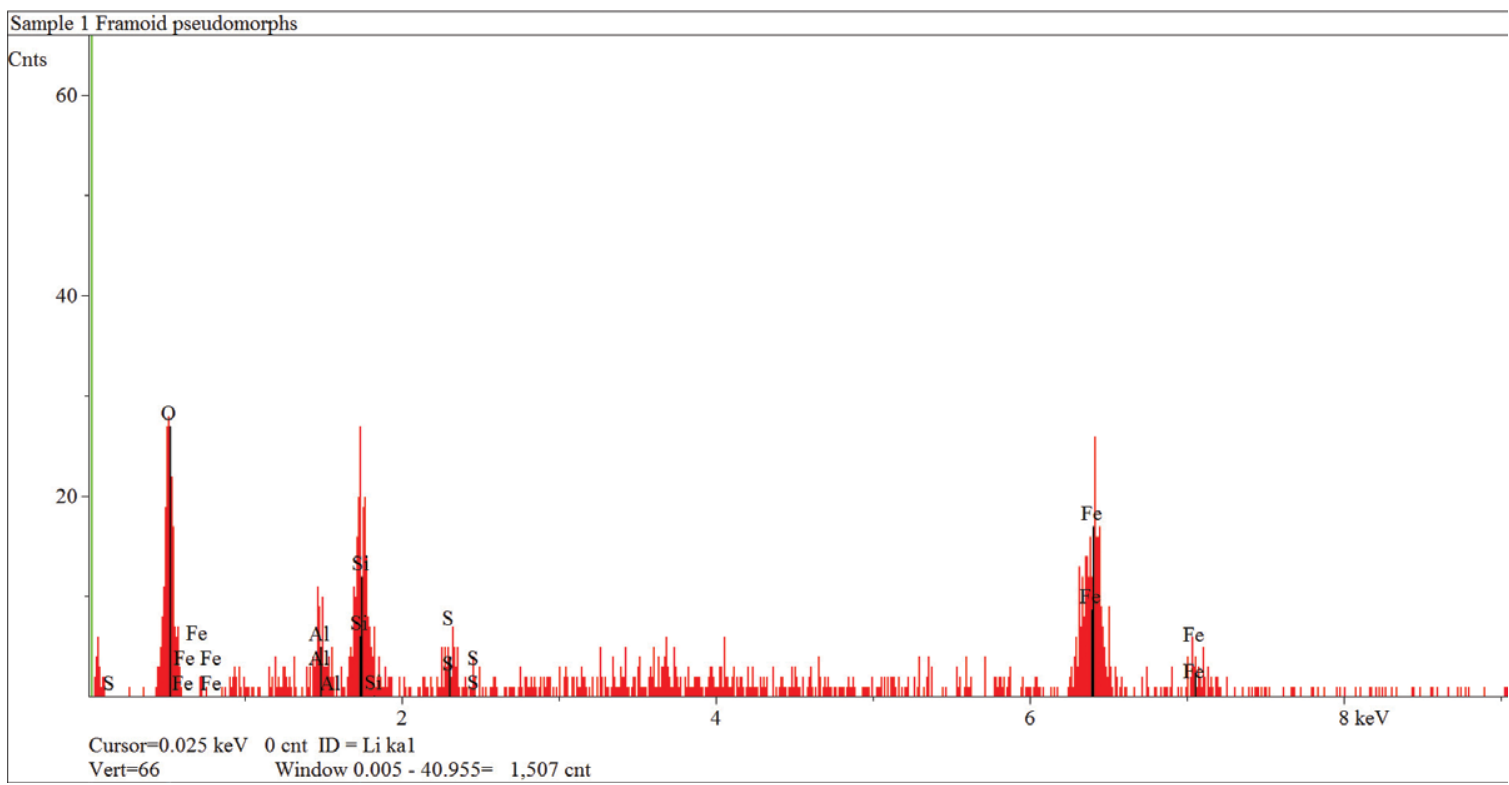

Figure 19. EDS counting peaks for framboidal pseudomorphs.

Many of the
framboids are
enclosed within
material inter-
preted as an
active biofilm,
with bacterial
stringers visi-
ble, as shown
in Figures 20
and 21 . Biofilm
that coats pyrite
has been de-
scribed as "ox-
idizing bacteria
attached to the
pyrite surface in
a matrix of ex-
tracellular, poly-
meric substanc-
s produced by
the bacteria"

(Crundwell, 1996). The biofilm observed via SEM matches that description and consists of "sub-micrometer cocci, smooth filaments, and chains of segmented bacteria" (Spilde, M., personal communication). If the biofilm is composed of $A$. ferrooxidans, then this is consistent with the observation that this bacteria oxidizes pyrite crystals by direct contact with the pyrite surface (Beck and Brown, 1968). To summarize, the SEM images provide support for the hypothesis that bacterially-assisted oxidation of pyrite in the shale has taken place.

\section{Cave Development}

As described above, the presence of smectite-family swelling clays enhances the transport of oxygen and surface water through the regolith to unweathered, fractured shale a few meters below. The resulting oxidation of pyrite 


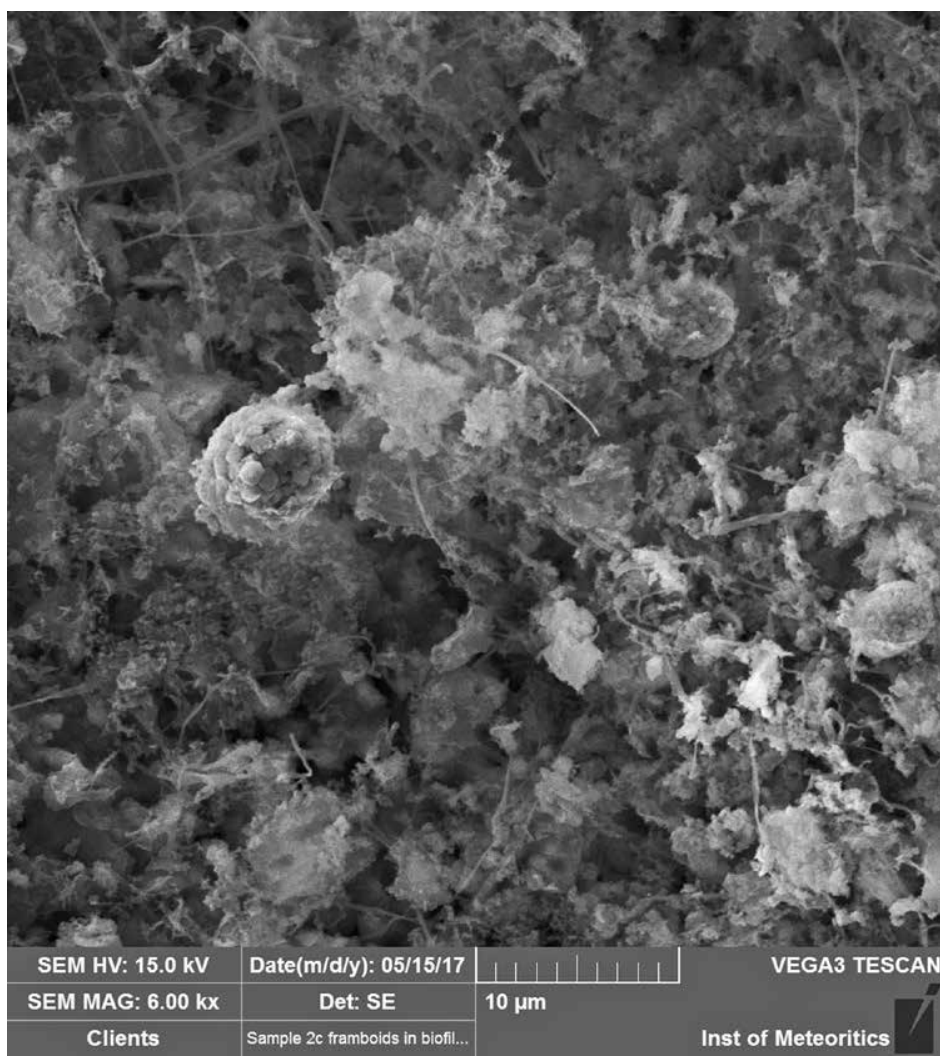

Figure 20. Framboidal pseudomorphs enclosed in biofilm with stringers.

has been documented in a variety of settings. For example, in Colorado, soil slumping, due to the dissolution of gypsum in the Pennsylvanian Eagle Valley evaporates, is described in White and Greenman, (2008): "dissolution of soluble soil constituents results in soil-mass loss and settlement of the ground surface." In a study conducted in Derbyshire, England, it was concluded that "chemical alteration of shale involving oxidation of pyrite, leaching of carbonates by sulphuric acid, formation of iron hydroxide minerals, and leaching of cations from clay minerals, is a rapid process that led to the collapse of a shale embankment" (Pye and Miller, 1990).

In the San Juan Basin, New Mexico, sandstone soil slumping in filled clastic pipes that result in downdropped beds (in pipes up to $9 \mathrm{~m}$ in diameter) are described in Hunter, R.E. et. al. (1992). They state that the down-dropped beds "can form by localized dissolution of an evaporite body formed by solution collapse," and conclude: "we doubt that mechanisms other than solution-induced collapse could have created the space

${ }^{3} \mathrm{The}$ molar volume of $\mathrm{CaSO} \cdot 2 \mathrm{H}_{2} \mathrm{O}=172 \mathrm{~g} / \mathrm{mol} / 2.32 \mathrm{~g} / \mathrm{cc}=74.137$ $\mathrm{cc} / \mathrm{mol} ; 1 \mathrm{cc}=.01349 \mathrm{~mol}$. The molar volume of $\mathrm{CaCO}_{3}=100 \mathrm{~g} /$ $\mathrm{mol} / 2.71 \mathrm{~g} / \mathrm{cc}=36.9 \mathrm{cc} / \mathrm{mol} ; 1 \mathrm{cc}=0.0271 \mathrm{~mol}$. One cc of $\mathrm{CaCO}_{3}$ converts to $(0.0271 / 0.01349)=2.009 \mathrm{cc}$ of $\mathrm{CaSO}_{4} \cdot 2 \mathrm{H}_{2} \mathrm{O}$. In (Palmer, 2007, p. 335), a similar calculation is carried out for the conversion of pyrite to gypsum. The molar mass of FeS2 $=120 \mathrm{~g} /$ $\mathrm{mol}$ and the density of FeS2 = $5 \mathrm{~g} / \mathrm{cc}$; thus $1 \mathrm{cc}$ of FeS2 $=0.04167$ mol. Since one cubic centimeter of gypsum $\approx 0.01349 \mathrm{~mol}$ and one mole of pyrite converts to two moles of $\mathrm{CaSO}_{4} \cdot 2 \mathrm{H}_{2} \mathrm{O}$, the conversion factor is $2 \times(0.04167 / .01349)=6.178$ (i.e., $1 \mathrm{cc}$ of $\mathrm{FeS}_{2}$ converts to $6.178 \mathrm{cc} \mathrm{CaSO} \cdot 2 \mathrm{H}_{2} \mathrm{O}$ ). in the shale leads to gypsum deposition and subsequent wedging apart of the shale beds. The conversion of calcite in the shale to gypsum results in a volume increase by a factor of about two (White and White, 2003, Penner et al., 1972), since the molar volume of gypsum, $74.14 \mathrm{cc} / \mathrm{mol}$, is about twice that of calcite, $36.90 \mathrm{cc} / \mathrm{mol}^{3}$.

Penner et al. (1972) states: "Although the volume increases by a factor of two, of greater importance is the force associated with the growth of gypsum crystals. Under ideal circumstances, this force can be extremely high ... resulting in much greater heave than would occur with simple volume expansion during formation." As the shale beds are forced apart, the secondary porosity of the shale increases, along with a loss of structural integrity, resulting from the separation of individual beds (Figs. 14 and 15). This process of heaving and fracturing of shale beds by gypsum, deposited along bedding and fracture planes, is described for the Cretaceous Mancos Shale in western Colorado (White and Greenman, 2008). A similar process is observed in the Cody Shale caves, formed in partially weathered, paralithic bedrock, where loose angular fragments and small blocks of shale, containing gypsum interbeds, can be removed from the wall by hand or with a rock hammer. These fragments form rubble slopes beneath the passage walls (Fig. 22).

Gypsum dissolution, leading to surface subsidence,

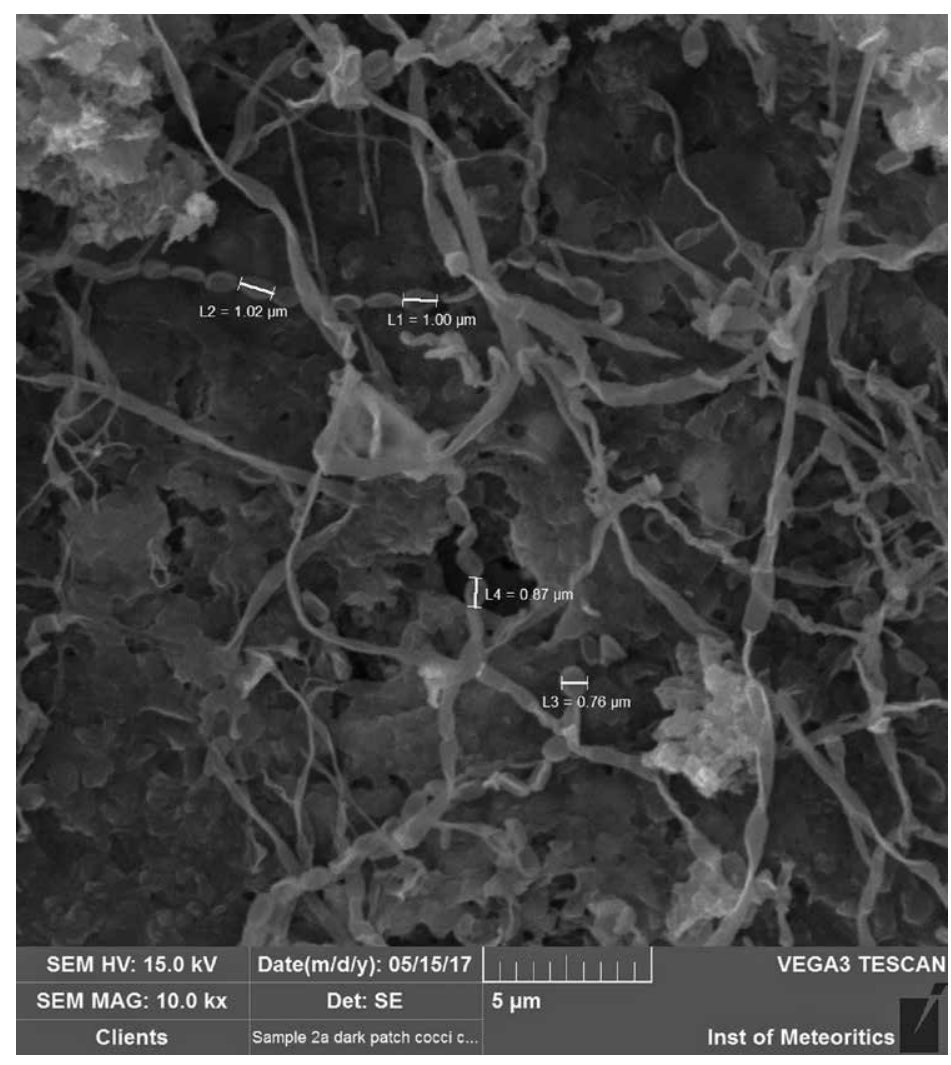

Figure 21. Cocci on bacterial stringers within biofilm. 


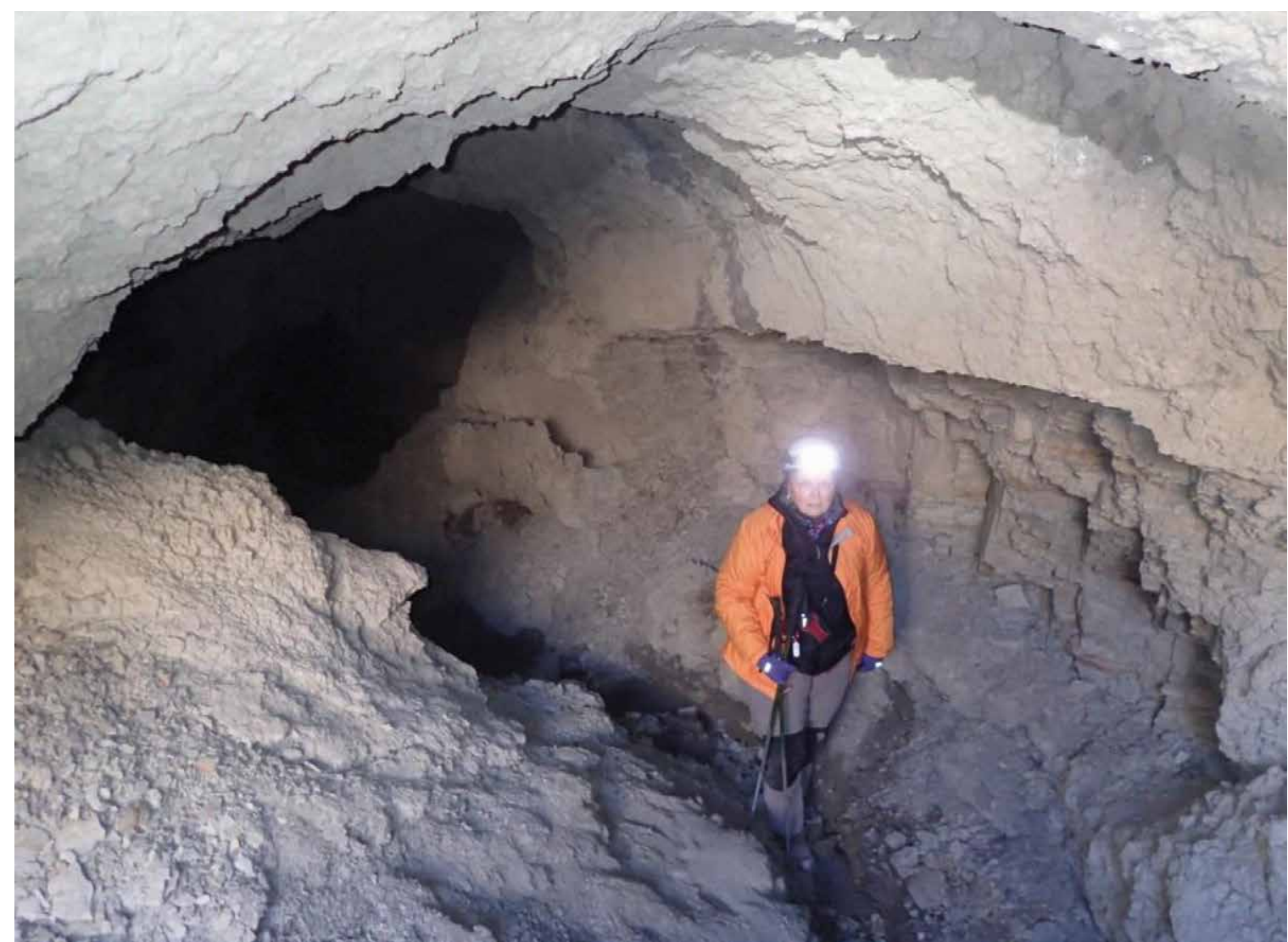

Figure 22. Cave passage illustrating arched ceiling, damp cave floor and lateral rubble slope. necessary for down dropping in the pipes."

None of these examples, however, describe conditions that are the same as observed in the Cody Shale caves in Wyoming, nor do they describe processes that led to the development of enterable cavities. However, it is argued that they are similar enough to provide some support for the sequence suggested in this paper. The closest analogue to what is observed in the Cody Shale caves is found in a report by White and Greenman, (2004) describing the development of openings in the Cretaceous Mancos Shale in western Colorado. The text states of that report states:

"fractures in claystone have been infilled with crystalline gypsum. The Mancos Shale was deposited in a deep-water, reduced environment and contains significant amounts of disseminated pyrite. Within the weathered zone, oxidation of pyrite creates sulfuric acid that reacts with available calcite in the shale to form gypsum. The gypsum tends to crystallize along bedding and fracture planes in the shale. The volume change when calcite recrystallizes to gypsum and during further growth of gypsum crystals can heave the claystone, physically fracturing, splitting, and jacking it apart. Subsequent wetting of this 'jacked' claystone can result in the dissolution of the gypsum, micropiping erosion, and creation of subsurface voids... Water from rainfall and snowmelt dissolves the gypsum in the shale, creating small voids, removing the broken/heaved shale fragments via corrasion."

A similar process appears to be taking place in the Cody Shale caves. Following the separation of shale beds from gypsum wedging, secondary porosity increases, allowing vadose water to flow through the spaces between the disassociated shale. When the water reaches an outlet point down-gradient on the hillside, sapping takes place with corrasional removal of particles and gradual opening of a void. As water continues to remove material, this void progresses headward with a proto-passage opening in an upstream direction, similar to passage enlargement in soil piping caves. Parker (1990) described this as "seepage-face erosion":

"water begins to seep from the bed at the point of highest permeability or lowest elevation in the face of the slope. As water leaves the slope, it carries away disaggregated and dispersed silt particles in suspension. This action initially creates a small orifice for the developing pipe in the cliff face."

Micron-scale clay particles, quartz grains, and other clastics are washed out by precipitation events. Given sufficient precipitation, this can take place fairly rapidly, resulting in a passage containing shale walls and ceiling, and a sediment floor consisting of a mix of clay, quartz, goethite, and other material. The shale walls tend to slough off as a result of continued gypsum wedging, leaving lateral ridges of broken shale paralleling the passages. Cantilevered ceiling blocks fall to the floor with the ceilings gradually stoping upward toward the center of the passage until structural stability is reached with 
an arched ceiling remaining, as shown in Figure 22. As water flows intermittently through the passage, a wetted, floor channel develops, also shown in Figure 22. A $0.3 \mathrm{~m}$ deep test pit, dug in a channelized floor (Fig. 23), revealed a transition from a bedrock wall to a damp matrix, most likely resulting from the disaggregation of spalling-shale wall material, as well as surface material washed in by precipitation events. The floor material, determined via XRD, consisted of 76

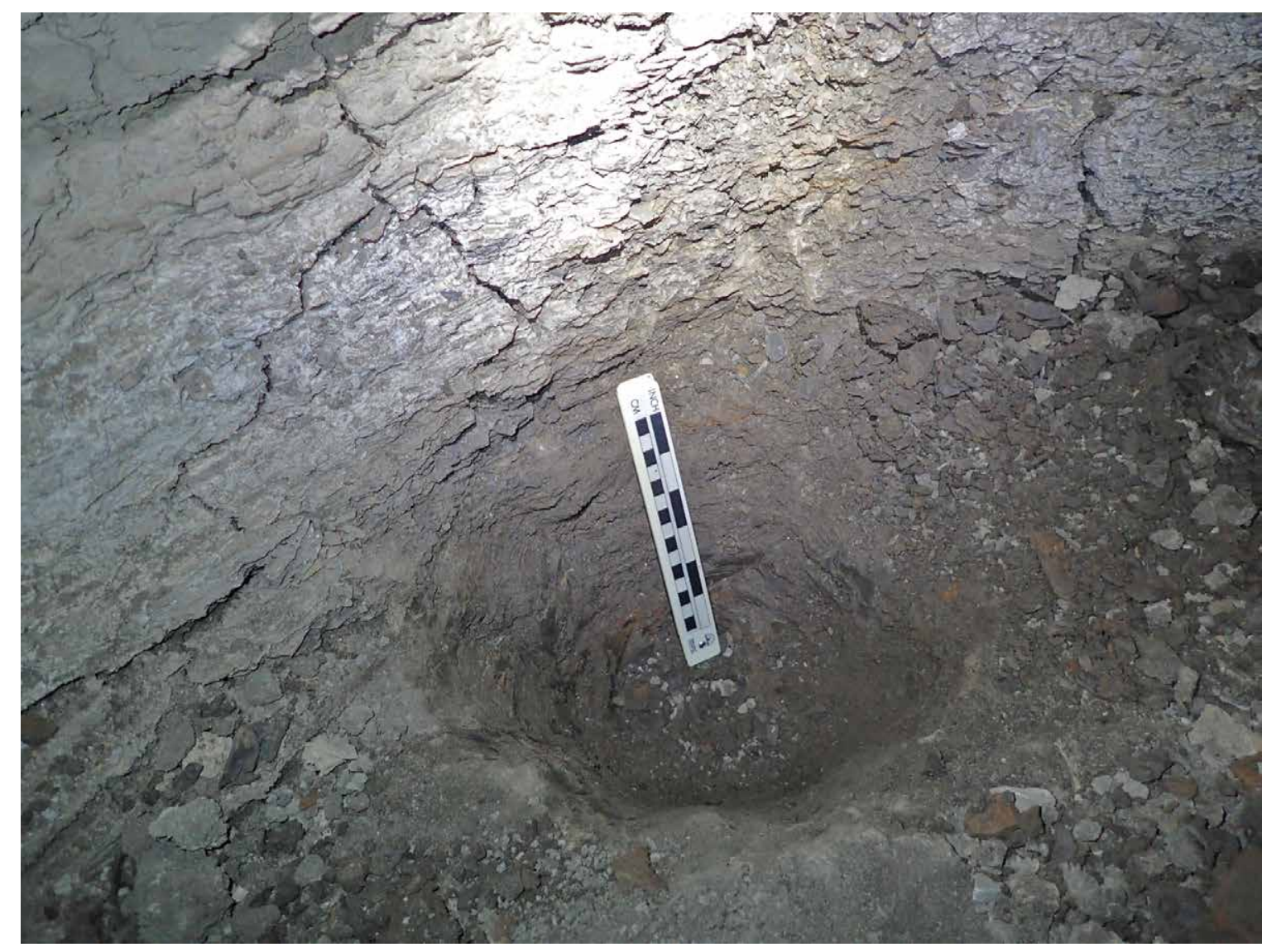

Figure 23. Test pit in cave passage floor showing transition from bedrock wall to damp, firm material. percent quartz, 6 percent gypsum, and a mix of chamosite and albite.

Clay particles were absent, perhaps indicating that material in the one- to five-micron range had been removed by flowing water, leaving larger particles to settle in the floor. In a paper on sediment transport in limestone caves, White and White (1968) write that "when very small particles in the clay and silt size-range are in suspension, it takes a long time for the material to fall out, and the load can be transported a long way before the water clears." A general relationship between the horizontal transport of material per unit of fall, expressed in feet per feet, and channel velocity, in feet per second for various grain sizes, is given in Figure 8 of that paper. Using that figure, for a conservative velocity of $0.03048 \mathrm{~m} / \mathrm{s}(0.1 \mathrm{ft} / \mathrm{s})$ and a grain size of $1 \mu \mathrm{m}$, typical of clay particles, the horizontal transport distance is somewhat over $305 \mathrm{~m} / \mathrm{m}$ of fall (1000 ft/ft of fall. This is sufficient for particles to remain in suspension for the distances observed between sink points and resurgences, typically on the order of tens of meters (hundreds of feet).

\section{Cave Evolution}

The processes described above take place over time but the rate at which caves develop and enlarge is not known. Two scenarios can be given:

1. The caves develop and enlarge quickly, but intermittently. Intense precipitation events, while infrequent, do occur. When this happens, sufficient water can move through the caves in short time periods to quickly enlarge proto-passages through wall scouring and corrasional removal of material, similar to suffosional soil piping cave processes. When immersed in water, the shale rapidly decomposes into clay particles. Gypsum-fractured shale in an environment where passages or proto-passages are immersed in storm waters should also decompose, allowing passages to rapidly enlarge. These events are interspersed with much longer time periods of low precipitation, when little or no passage enlargement may take place.

2. The caves develop slowly, but continuously. Small, but relatively higher frequency precipitation events and snowmelt result in soils and shale remaining seasonally damp with shale decomposition taking place on a semi-continuous basis. Over time, small quantities of floor and wall material are removed at a low but continuous rate.

Either one, or more likely, a combination of both scenarios may account for the development of the caves. 


\section{Age of the Caves}

Determining or estimating a minimum age for the Cody Shale caves presents challenges not present when dating caves in carbonate rocks or in basalts. Commonly used methods include dating using ${ }^{230} \mathrm{Th} /{ }^{234} \mathrm{U}$ decay, dating using ${ }^{40} \mathrm{~K} /{ }^{40} \mathrm{Ar}$ or ${ }^{40} \mathrm{Ar} /{ }^{39} \mathrm{Ar}$ ratios, cosmogenic dating using autochtonous quartz pebbles in or beneath passage floors, and carbon-14 dating. In the absence of calcite speleothems, gypsum crusts, a source of potassium, quartz pebbles, and organic material in the caves, these quantitative methods cannot be used.

Qualitatively, the caves appear to be old in terms of their life cycle. The caves are found in small surface catchments; typically 0.5 to 2.5 ha in area (mean basin size $=1.4$ ha). Considering the small catchment areas and low annual precipitation of $22 \mathrm{~cm}$ water equivalent per year, insufficient quantities of water move through the caves to allow corrasion-induced passage enlargement or even to remove material currently being spalled from passage walls. Based on limited observations to date, the cave entrances appear to be gradually infilling with surface material resulting from soil slumps. Possibly as a result of a lack of flowing water in the caves, entrances are not being washed open. Also, all of the caves contain passages that either end downstream in rubble chokes or become too narrow to follow; none of the caves contain lower entrances where water resurges even though sediment-choked rise points are seen. Given the current static environment in which the caves are found, it can be speculated that the caves may have developed in a wetter, perhaps post-Pleistocene periglacial environment; however, there is no evidence to support this. Unless datable material can be found in the caves, it will not be possible to quantitatively estimate their minimum ages.

\section{Process Summary}

The following sequence is proposed to explain the presence of caves in, and related landforms on, the Cody Shale.

1. Rainfall and snowmelt move downward through soil and reach the top of unweathered shale a few meters below. Some soil swell/shrink properties associated with the presence of swelling clays, such as montmorillonite, also assist water and oxygen movement downward by forming desiccation cracks, which eventually enlarge to produce small dolines. Water then moves through the shale below via joints, faults, and bedding partings.

2. Water and oxygen react with disseminated pyrite in the shale, resulting in formation of $\mathrm{H}_{2} \mathrm{SO}_{4}$ and leaving a ferric oxyhydroxide residue as concentrated fillings on cave passage walls, and as a coating on framboidal pyrite pseudomorphs. Essentially, all of the pyrite in the shale is depleted.

3. The $\mathrm{H}_{2} \mathrm{SO}_{4}$ and acidic meteoric water react with calcite in the shale, depleting the calcite and producing gypsum fracture fillings that wedge the shale beds apart and structurally weaken them.

4. As the shale beds separate because of gypsum-induced wedging, small, open voids are created, allowing additional water to contact the shale. Corrasional processes remove fine particles (about $2 \times 10^{-3} \mathrm{~mm}$ diameter), on a grain by grain basis, enlarging the voids.

5. As a result of the removal of material, slumping occurs on the surface, allowing a more localized flow of surface water and additional oxygen to reach the fractured shale below, enhancing the process. As vadose water moves through the fragmented shale, the local hydraulic gradient permits water to flow downhill to a discharge point, where sapping takes place. At this point, a proto-passage develops with gradual headward enlargement due to corrasional removal of material. This allows larger and more continuous voids to develop until integrated passages remain.

6. Continued surface slumping from upward stoping of the ceiling, and removal of material below, results in isolated, hillside dolines developing that intersect the voids and allow additional surface water to reach the shale.

\section{Conclusions}

The proposed sequence of events leading to the development of the caves observed in the Cody Shale is based on known processes for surface weathering of clay soils, pyrite oxidation, gypsum deposition, shale heaving resulting from replacement of pyrite by gypsum, and granular removal of broken shale and clay particles by corrasional processes. Although all of these processes commonly occur, caves that develop as a result have not been reported and require an unusual set of circumstances (e.g., a swelling soil, sufficient pyrite and calcite in the shale, fracturing of the shale allowing oxygen to circulate, a hydraulic gradient sufficient for material to be removed and a discharge point). If these conditions are met, then as outlined in this paper, enterable caves can result.

\section{Acknowledgments}

The work described in this paper was supported by analyses conducted at several laboratories. The soil analyses were carried out by the Soil, Water, and Plant Testing Laboratory at Colorado State University. X-Ray diffraction analyses and diffractograms were conducted by the XRD laboratory at the New Mexico Bureau of Geology and Mineral Resources in Soccoro, New Mexico. Virgil Lueth, laboratory manager, provided valuable insights in conversations about the XRD results. Richard Heemskerk at the Environmental Isotope Laboratory, Department of Earth and Environmental 
Science, University of Waterloo in Ontario, Canada, did the stable sulfur isotope analysis of the gypsum samples collected in caves. Scanning electron microscopy and energy dispersive spectroscopy of shale samples was conducted by Michael Spilde, manager of the Electron Microprobe and Scanning Electron Microscope labs at the University of New Mexico in Albuquerque, N.M. The images obtained provided evidence for the role of microbes in oxidizing pyrite; Mike's observations and insights were especially helpful. Review comments and suggestions made after reading earlier drafts of this paper were provided by William B. White, Arthur Palmer, John Mylroie, and Ed LaRock. These comments and e-mail exchanges provided valuable feedback and guidance. Finally, comments and support in the field was provided by Hazel Medville without whose help, the data and photographs needed to support this work could not have been obtained.

\section{References}

Beck, J.V. and Brown, G.D., 1968, Direct sulfide oxidation in the solubilization of sulfide ores by Thiobacillus ferrooxidans, Journal of Bacteriology, v. 96, p. 1433-1434.

Brantley, S.L., Hollerin, M.E., Jin, L., and Bazilevskaya, B., 2013, Probing deep weathering in the Shale Hills Critical Zone Observatory, Pennsylvania (USA): the hypothesis of nested chemical reaction fronts in the subsurface: Earth Surface Processes and Landforms, v. 38, no. 11, p. 1280-1298. https://doi.org/10.1002/esp.3415.

Carroll, D., 1959, Ion exchange in Clays and Other Minerals, GSA Bulletin, v. 7, no. 6, p. 749-779. https://doi.org/10.1130/0016-7606(1959)70[749 :IEICAO]2.0.CO;2

Crundwell, F., 1996, The formation of biofilms of iron-oxidizing bacteria on Pyrite in Minerals in Engineering, v. 9, no. 10, p. 1081-1089.

Finn, T.M., 2013, Lower Cody Shale (Niobrara equivalent) in the Bighorn Basin, Wyoming and Montana: thickness, distribution, and source rock potential. U.S. Geological Survey Scientific Investigations Report 2013, 5138, 32 p.

Granger, D.E. and Fabel, D., 2005, Cosmogenic isotope dating in Culver, D.C. and White, W.B. (eds.), Encyclopedia of Caves, Elsevier Academic Press, London, p. 137-141.

Hunter, R.E., Gelfenbaum, G., and Rubin, D.M., 1992, Clastic pipes of probable solution-collapse origin in Jurassic rocks of the Southern San Juan Basin, New Mexico. U.S. Geological Survey Bulletin 1808-L, 19p.

Hoover, S.E., Wang, M.C. and Dempsey, B., 2004, Structural damage induced by pyritic shale, Fifth International Conference on Case Histories in Geotechnical Engineering Paper 7.02, p. 1-7.

Kelly, D.P. and Wood, A.P, 2000, Reclassification of some species of Thiobacillus to the newly- designated genera Acidithiobacillus gen. nov., Halothiobacillus gen. nov. and Thermithiobacillus gen. nov. in International Journal of Systematic and Evolutionary Microbiology 50: 511-516. https://doi.org/10.1099/00207713-50-2-511.

Lupton, C.T., 1916, Oil and gas near Basin, Big Horn County, Wyoming. Geological Society of America Bulletin 621, p. 157-190.

Nordstrom, D.K., 1982, Aqueous pyrite oxidation and the consequent formation of secondary iron minerals. Chapter 3 in Acid Sulfate Weathering, Soil Science Society of America, p. 56-77.

Palmer, A.N., 2007, Cave Geology. Cave Books, Dayton, Ohio.

Parker, G.G. and Higgins, C.C., 1990, Piping and pseudokarst in drylands in Higgins, C.G. and Coates, D.R. (eds.), Geological Society of America Special Paper 252, Groundwater Geomorphology: The Role of Subsurface Water in Earth-Surface Processes and Landforms, p. 77-110. https://doi.org/10.1130/SPE252-p77.

Paytan, A., Gray, E.T., Ma, Z., Erhardt, A., and Faul, K., 2011, Application of sulphur isotopes for stratigraphic correlation. Isotopes in Environmental and Health Studies. p. 1-12.

Penner, E. and Eden, W.J., 1972, CBD-152, Expansion of pyritic shales. Canadian Building Digest, Division of Building Research, National Research Council Canada, $6 \mathrm{p}$.

Pierce, W.G., 1948, Geologic and structure contour map of the Basin-Greybull area, Big Horn County, Wyoming. U.S.G.S. Oil and Gas Investigation Map OM-77, scale 1:48000, one sheet.

Pye, K. and Miller, J.A., 1990, Chemical and biochemical weathering of pyritic mudstones in a shale embankment in Quarterly Journal of Engineering Geology and Hydrogeology, v. 23, p. 365-382.

RRUFF Database, 2017, http://rruff.info/goethite/display=default/R050142.

Soil Quality Organization website, Australia, 2017, Cations and Cation Exchange Capacity Factsheet. http://www.soilquality.org.au/factsheets/ cation-exchange-capacity.

Taylor, G. and Eggleton, R.A., 2001, In situ weathering profiles in Regolith Geology and Morphology, Chapter 11, p. 191-218, John Wiley and Sons, New York.

Thode, H.G., 1991, Sulphur isotopes in nature and the environment: an overview in H.R. Krouse and V.A. Grinenko, (eds.), Soluble Isotopes in the Assessment of Natural and Anthropogenic Sulphur in the Environment. John Wiley and Sons, Chichester. p. 1-26.

U.S. Department of Agriculture, Natural Resources Conservation Service, Web Soil Survey, Published Soil Survey for Wyoming, Bighorn County area, 2017. https://www.nrcs.usda.gov/wps/portal/nrcs/surveylist/soils/survey/state?stateld=WY.

U.S. Department of Energy, Environmental Sciences Laboratory, 2011, Natural contamination from the Mancos Shale, Report ESL-RPT-2011-01, p. 46-47.

White, E.L. and White, W.B., 1968, Dynamics of sediment transport in limestone caves in Bulletin of the National Speleological Society. v. 30 , no. 4, p. 115-129.

White, J.L. and Greenman, C., 2008, Collapsible soils in Colorado. Colorado Geological Survey Publication EG-14, 108 p.

White, W.B. (ed.), 2015, The Caves of Burnsville Cove, Virginia, Springer, New York, p. 436-437. https://doi.org/10.1007/978-3-319-14391-0.

White, W.B. and White, E.L., 2003, Gypsum wedging and cavern breakdown: Studies in the Mammoth Cave System, Kentucky in Journal of Cave and Karst Studies, v. 65, no. 1, p. 43-52. 